\title{
Factors affecting the distribution of Pyrodinium bahamense var. bahamense in coastal waters of Florida
}

\author{
E. J. Phlips*, S. Badylak, E. Bledsoe, M. Cichra \\ Dept. Fisheries and Aquatic Sciences, University of Florida, 7922 N.W. 71st Street, Gainesville, Florida 32653, USA
}

\begin{abstract}
Over the last half of the 20th century Pyrodinium bahamense var. bahamense has been observed in a variety of locations in the western North Atlantic. Recent evidence of the toxinproducing capacity of this variety of $P$. bahamense has heightened interest in its habitat requirements and preferences. The objective of this study was to examine the environmental factors that relate to the spatial and temporal patterns of the distribution and abundance of $P$. bahamense var. bahamense. Based on the results of this study we view the factors as operating in one or more ways: (1) ecophysiological limitations for survival and successful reproductive cycle, (2) environmental regulation of growth and standing crop, and (3) competitive advantages in relation to other species. The focus of the study was the Florida peninsula, but information from other environments in the tropical Atlantic and Gulf of Mexico was included in the interpretation of the results. In terms of physiological limitations, $20^{\circ} \mathrm{C}$ appears to be the lower temperature limit for a significant presence of $P$. bahamense var. bahamense, and the salinity tolerance ranged from 10 to 45 . The bloom potential of $P$. bahamense var. bahamense was most closely associated with shallow ecosystems with long water residence times, and peak biomass levels were correlated to nutrient concentrations in regions of high abundance. The ability of $P$. bahamense var. bahamense to compete effectively for habitat with other euryhaline warm-water phytoplankton is viewed in terms of existing theories on succession and competition, including Margalef's Mandala, Reynolds' Intaglio and C-S-R life-form strategies proposed by Smayda \& Reynolds.
\end{abstract}

KEY WORDS: Phytoplankton · Succession · Tropical Atlantic Ocean · Gulf of Mexico · Dinoflagellate · Harmful algae $\cdot$ Saxitoxin

\section{INTRODUCTION}

The prominence of the toxic bioluminescent dinoflagellate Pyrodinium bahamense var. compressum in the tropical Indo-Pacific region has been extensively described (Maclean 1989, Shumway 1990, Hallegraeff 1993, Smayda 1997, Anton et al. 2000, Azanza \& Taylor 2001); however, the distribution of its Atlantic Ocean counterpart, $P$. bahamense var. bahamense, is less well defined. One of the earliest reports of $P$. bahamense in the North Atlantic came from the Bahamas by Plate (1906). Later, Margalef (1961) reported blooms of $P$. bahamense in Phosphorescent Bay, an aquatic habitat in Puerto Rico named for the light emissions attributable to the dinoflagellate. In the early accounts of $P$. bahamense var. bahamense, no distinct varietal status was assigned to the Atlantic form, but subsequent morphological studies suggest that such a distinction is warranted (Steidinger et al. 1980, Badylak et al. 2004), although not universally accepted (Balech 1985). Over the last half of the 20th century $P$. bahamense var. bahamense has been observed in a variety of additional locations in the western North Atlantic, including Oyster Bay in Jamaica (Seliger et al. 1970), and Florida Bay (Phlips \& Badylak 1996), Indian River Lagoon (Badylak \& Phlips 2004), and Tampa Bay (Steidinger et al. 1980, Badylak et al. 2006) in Florida. 
One of the most noteworthy features of Pyrodinium bahamense is the ability of the Indo-Pacific form, P. bahamense var. compressum, to produce saxitoxin, a powerful neurotoxin responsible for widespread human mortalities in the Indo-Pacific region (Maclean 1989, Azanza \& Taylor 2001). Until recently, it had been assumed that the Atlantic form of $P$. bahamense did not produce the neurotoxins associated with $P$. bahamense var. compressum (Steidinger et al. 1980, Azanza \& Taylor 2001). However, recent studies of saxitoxin bioaccumulation in pufferfish from the Indian River Lagoon in Florida led to the discovery that local strains of P. bahamense (var. bahamense) can produce the toxin (Landsberg et al. 2002). This discovery has heightened interest in the factors that regulate the presence and abundance of $P$. bahamense var. bahamense.

Another recent observation about the Atlantic form of Pyrodinium bahamense var. bahamense is its ability to form blooms under low-salinity conditions (i.e. salinities <25) (Phlips et al. 2004a). Such conditions are found in many lagoons and estuaries in Florida. It had been previously hypothesized that blooms of $P$. bahamense var. bahamense were restricted to regions of higher salinities (i.e. salinities > 30) (Wall \& Dale 1969), much like the prominent toxic dinoflagellates Karenia breve and Gamberodiscus toxicus. This observation expands the potential realm of influence for $P$. bahamense var. bahamense.

The objective of the present study was to examine the environmental factors that relate to the spatial and temporal patterns of the distribution and abundance of Pyrodinium bahamense var. bahamense. Based on the results of this study we view the factors as operating in one or more ways: (1) ecophysiological limitations for survival and successful reproductive cycle, such as temperature and salinity tolerances; (2) environmental regulation of growth and standing crop, such as nutrient availability; and (3) competitive advantages in relation to other species, such as growth rate potential. The focus of the study was the Florida peninsula, but information from other environments in the tropical Atlantic and Gulf of Mexico was included in the interpretation of the results. The study was aided by the large variety of environmentally distinct coastal habitats encountered in Florida. Florida is also known as a biogeographical transition zone from the tropical habitats of the Florida Keys to the warm temperate regions of the Georgia and Carolina coasts. The results of this study are discussed within the context of current hypotheses regarding the factors that favor blooms of dinoflagellates (Margalef et al. 1979, Reynolds \& Smayda 1998, Smayda \& Reynolds 2001), including nutrient status, hydrologic conditions, and biological interactions. As suggested by Reynolds and Smayda (Reynolds \& Smayda 1998, Smayda \& Reynolds 2001), 'life form properties, habitat preferences and stochastic selective processes' are more important in defining the character of succession and the magnitude of blooms than broad phylogenetic associations.

\section{MATERIALS AND METHODS}

Study site descriptions. In an effort to describe the distribution and prominence of Pyrodinium bahamense var. bahamense within Florida, phytoplankton composition data gathered by the authors since 1993 and information from existing literature were both used in this study. In the former category, data were available for 20 sampling sites along the east coast of Florida, 18 sites in Florida Bay at the southern tip of Florida, and 34 sites along the western coast of the Florida peninsula, focusing on Tampa Bay and the Suwannee River estuary (Fig. 1).

The northernmost sampling sites along the east coast of Florida were located in the mesohaline portion of the St. Johns River. The lower reach of the St. Johns River extends $175 \mathrm{~km}$, from Lake George to the Atlantic

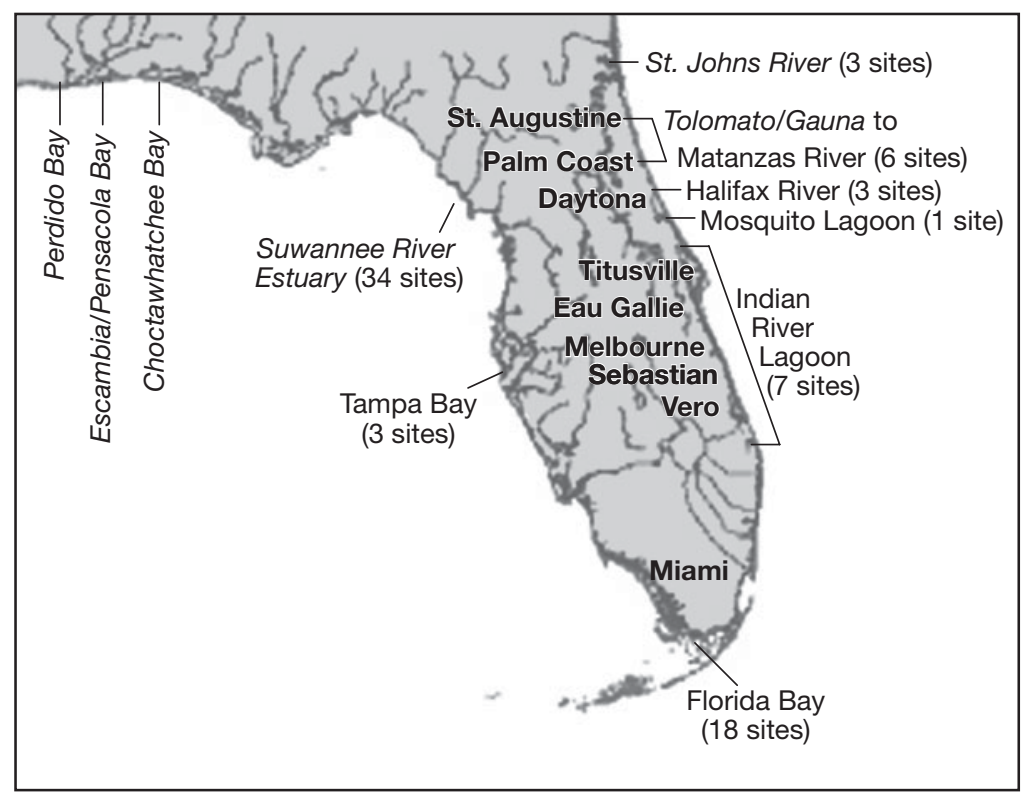

Fig. 1. Locations of sampling sites on the peninsula of Florida. In addition to sites examined in the current study, literature accounts of phytoplankton studies were also considered from 3 locations in the panhandle of Florida. Regions where Pyrodinium var. bahamense was not observed or reported by other researchers are shown in italics 
Ocean. Due to the very shallow slope of the river basin, the influence of oceanic water can extend up to $75 \mathrm{~km}$ upstream of the outflow. Much of the river is shallow, i.e. $<4 \mathrm{~m}$ in depth, with the exception of the dredged navigational channels. Phytoplankton composition data were available for 3 sampling sites within the mesohaline portion of the river on a monthly basis for a $12 \mathrm{yr}$ period from 1993 through 2005. The 5 sites were located from 4 to $70 \mathrm{~km}$ from the outflow.

South of the St. Johns River, the sampling sites along the east coast of Florida were mostly located in the lagoonal habitats between the barrier islands and mainland of Florida. The Intra-Coastal Waterway extends for almost the entire length of the east coast of Florida connecting the various lagoons. All of the lagoons are characterized by shallow mean depth, i.e. generally $<3 \mathrm{~m}$, except in dredged navigational channels. Inlets to the Atlantic Ocean are located along the entire reach of the waterway and represent the major points of water exchange with the Atlantic Ocean. Distance from the inlets is a major factor determining water residence time, along with the size of freshwater inflows from local watersheds. Sampling sites were located in 5 major lagoons. One sampling site located in the Guana-Tolomato River Lagoon, just north of St. Augustine, was sampled approximately monthly from 2000 through 2005. Five sampling sites located in the Matanzas River Lagoon, from St. Augustine to Palm Coast, were sampled approximately monthly from 2000 through 2005. Three sampling sites located in the Halifax River Lagoon, from Flagler Beach to New Smyrna, were sampled approximately monthly from 2000 through 2002. The largest block of data was from the Indian River Lagoon, which extends $252 \mathrm{~km}$ from the warm temperate environment near Titusville to the subtropical region of Jupiter inlet near Ft. Pierce. The width of the lagoon varies from 0.1 to $3 \mathrm{~km}$, and depths in the lagoon are generally $<3 \mathrm{~m}$. A number of ecologically distinct regions exist within the lagoon, which differ considerably in water quality and hydrologic properties (Sheng et al. 1990, Smith 1993, Phlips et al. 2002, 2004b). Hydrodynamic considerations are a large component in the subdivision of the lagoon into different regions. Eight study sites, representative of the different regions, were sampled on approximately a monthly basis from 1997 to 2005. Due to the restriction of water exchange in many regions of the lagoon, changes in rainfall patterns can lead to large shifts in salinity (Phlips et al. 2002, 2004).

At the southern tip of Florida, 18 sites were sampled in Florida Bay, a restricted $1600 \mathrm{~km}^{2}$ inner-shelf lagoon located south of the Everglades and west of the Florida Keys. Depths within the bay are generally $<3 \mathrm{~m}$. A network of very shallow mud banks, located throughout the bay, restrict water exchange between the inner regions of the bay and the Atlantic Ocean and Gulf of Mexico. The locations of the 18 sites were selected to be representative of the major sub-basins within the lagoon (Phlips et al. 1996, 1999). Water was collected monthly from 1993 to 1997.

Along the west coast of Florida 2 major regions were included in the sampling effort, Tampa Bay and the Suwannee River estuary. Tampa Bay is Florida's largest estuary, with a surface area of $1031 \mathrm{~km}^{2}$. The estuary has a mean depth of $3.7 \mathrm{~m}$ (Schmidt \& Luther 2002). Water samples were collected from 3 sampling sites in the bay, 1 near the mouth of the bay, 1 in the center of the bay, and 1 in the northern basin of the bay, known as Old Tampa Bay. The latter sampling site is characterized by long residence times caused by the relatively small freshwater inflows to the northern basin and the physical restriction to tidal water exchange due to causeway constrictions and shoals (Schmidt \& Luther 2002). Samples were collected approximately 3 times per month from April 2002 through April 2003.

The Suwannee River is a blackwater river that originates in the Okefenokee Swamp in southeastern Georgia and winds southward $394 \mathrm{~km}$ to the Gulf of Mexico. The Suwannee River, with its tributaries the Alapaha, Withlacoochee, and Santa Fe Rivers, drains approximately $28500 \mathrm{~km}^{2}$ of southern Georgia and northcentral Florida. Freshwater discharge is augmented by substantial groundwater contributions from numerous springs along the river. The Suwannee River has the second highest mean annual discharge of any river in Florida, i.e. $301 \mathrm{~m}^{3} \mathrm{~s}^{-1}$. A network of 34 fixed sampling sites, in coastal waters adjacent to the Suwannee River outflow, was sampled monthly from 1998 to 2003. The locations of the sampling sites were designed to incorporate ecologically distinct regions of the estuary, based on several key physical, chemical, and biological features (Bledsoe \& Phlips 2000, Bledsoe et al. 2004). The Suwannee River coastal area includes a delta region near the river mouth, which is characterized by a network of oyster reefs. The coastal area is characterized by a shallow mean depth, i.e. generally $<3 \mathrm{~m}$, except in dredged navigational channels and seaward of the oyster reef. Beyond the oyster reef is a broad continental shelf habitat.

Field procedures. Water was collected at the sampling sites using a vertical, integrating sampling tube that captures water from the surface to within $0.1 \mathrm{~m}$ of the bottom. Salinity and temperature were measured with a YSI Model 85 and with Hydrolab Quanta environmental multi-probes. Split phytoplankton samples were preserved with Lugol's and gluteraldehyde in $0.1 \mathrm{M}$ sodium cacodylate buffer. Aliquots of water were filtered for chlorophyll a determination. Additional aliquots of water were frozen for subsequent water chemistry analysis. 
Laboratory procedures. Total nitrogen and total phosphorus were determined colorimetrically using the persulfate digestion method (APHA 1989, Parsons et al. 1984).

Chlorophyll a was determined with a Hitachi U2000 dual beam spectrophotometer from water samples filtered onto Gelman A/E glass-fiber and extracted with 95\% ethanol (Sartory \& Grobbelaar 1984).

Phytoplankton analysis. General phytoplankton composition was determined using the Utermöhl method (Utermöhl 1958). Samples preserved in Lugol's were settled in $19 \mathrm{~mm}$ internal diameter cylindrical chambers. Phytoplankton cells were identified and counted at $400 \times$ and $100 \times$ with a Leica phase contrast inverted microscope. At $400 \times$, a minimum of 100 cells of a single taxon and 30 grids were counted. If 100 cells were not counted by 30 grids, up to a maximum of 100 grids were counted until 100 cells of a single taxon was reached. At 100x, a total bottom count was completed for taxa $>30 \mu \mathrm{m}$. Light microscopy was aided by other techniques for proper identification, such as the squash technique (Steidinger 1979) and scanning electron microscopy (Badylak et al. 2004).

Fluorescence microscopy was used to enumerate picoplanktonic cyanobacteria (Fahnenstiel \& Carrick 1991). Subsamples of seawater were filtered onto $0.2 \mu \mathrm{m}$ pore Nuclepore filters and mounted between a microscope slide and cover slip with immersion oil. These were stored in the freezer and counted within $72 \mathrm{~h}$ using a Nikon research microscope equipped with autofluorescence (green light 530 to $560 \mathrm{~nm}$ excitation and $>580 \mathrm{~nm}$ emission).

Cell biovolumes were estimated by assigning combinations of geometric shapes to fit the characteristics of individual taxa. Specific phytoplankton dimensions were measured for at least 30 randomly selected cells. Volumes were calculated for each cell from which a mean cell volume was derived (Smayda 1978). The total biovolume per sample was the sum of the estimated cell volumes for each species. Mean biovolume for Pyrodinium bahamense var. bahamense was $67064 \mu^{3}$.

Statistical analysis. Canonical correspondence analysis (CCA; PC-ORD, v. 4.0) is a direct gradient analysis technique that constrains the extracted pattern to linear combinations of the measured environmental variables (ter Braak 1987). CCA was used to characterize the relationships among Pyrodinium cell density and relative abundance (\% of total phytoplankton biovolume), and 5 environmental variables, salinity, temperature, total phosphorus (TP), total nitrogen (TN), and water retention time index (RTI). Prior to statistical analysis, all variables were transformed using the $\left[\log _{10}(x+1)\right]$ transformation. The contribution of each set of variables was estimated independently using the sum of canonical eigenvalues, and the statistical significance was assessed by Monte Carlo permutation tests of the sum of all eigenvalues, using 1000 permutations.

\section{RESULTS}

The most general spatial pattern revealed by the available data was the absence of Pyrodinium bahamense var. bahamense north of the Matanzas Inlet on the east coast of Florida and north of Tampa Bay on the west coast of Florida (Fig. 1). South of these 2 regions the presence of $P$. bahamense var. bahamense showed both temporal and spatial variability. Among the sites where $P$. bahamense var. bahamense was observed, there was considerable variability in the frequency of occurrence and the maximum biomass attained by $P$. bahamense var. bahamense (Table 1). Three regions were particularly abundant in P. bahamense var. bahamense: Florida Bay, Tampa Bay, and the Indian River Lagoon. The eastern part of Florida Bay had the highest frequency of occurrence (Table 1), but not the highest biomass or relative importance in terms of total phytoplankton biovolume (Fig. 2). The highest P. bahamense var. bahamense biomass was observed in the inner reaches of Tampa Bay and the northern portion of the Indian River Lagoon, with cell densities of up to 380 and 776 cells ml ${ }^{-1}$ and cell biovolumes of up to 25

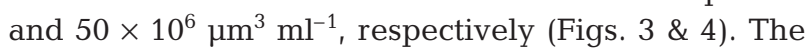
latter regions also exhibited the greatest dominance of $P$. bahamense var. bahamense in terms of total phytoplankton biomass. In both regions $P$. bahamense var. bahamense represented $>80 \%$ of total phytoplankton biovolumes on numerous occasions (Figs. $3 \& 4$ ).

In regions where Pyrodinium bahamense var. bahamense was prominently represented, different temporal patterns of abundance were discernible. In the tropical/subtropical environment of Florida Bay, P. bahamense var. bahamense was observed nearly yearround (Fig. 2). In the subtropical/warm temperate environments of the Indian River Lagoon and Tampa Bay, $P$. bahamense var. bahamense was generally restricted to the warm season, i.e. April through October (Figs. 3 \& 4). Outside the periods of $P$. bahamense var. bahamense dominance, other taxa, like picoplanktonic cyanobacteria or diatoms, often showed peaks in abundance, as exemplified in the phytoplankton record for Tampa Bay (Fig. 5).

From a broader temporal perspective, the distribution of Pyrodinium bahamense var. bahamense in the Indian River Lagoon showed a response to longer term climatic cycles, like El Niño and La Niña, and stochastic rainfall events. Over the 9 years of sampling in the Indian River Lagoon from 1997 to 2005, P. bahamense var. bahamense abundance was low during the pro- 
longed drought period from the fall of 1998 through the early summer of 2001 (Fig. 4). By contrast, P. bahamense var. bahamense densities were dramatically elevated during the high rainfall period from the summer of 2001 through 2004 (Fig. 4). Similarly, large blooms of $P$. bahamense var. bahamense were observed in the summer of 2002 in Tampa Bay (Fig. 3).

The spatial and temporal patterns of Pyrodinium bahamense var. bahamense occurrence and abundance observed in this study provided an opportunity to examine relationships with environmental factors that may play a role in the distribution of the species. The relationships between temperature and abundance in the Indian River Lagoon, Tampa Bay, and Florida Bay support the notion that $P$. bahamense var. bahamense is restricted to periods of high temperature (Fig. 6). In general, $P$. bahamense var. bahamense was only observed at water temperatures of $20^{\circ} \mathrm{C}$ or greater. Blooms were largely confined to temperatures $>25^{\circ} \mathrm{C}$. A few exceptions to this rule were observed. For example, $P$. bahamense var. bahamense was observed in a sample from Florida Bay when the water temperature at the time of sampling was $15^{\circ} \mathrm{C}$. However, closer examination of the temperature record for Florida Bay indicated that the $15^{\circ} \mathrm{C}$ temperature was a result of a strong cold front that briefly depressed water temperatures in the shallow reaches of the bay. Immediately prior to the cold front, water temperatures were near $25^{\circ} \mathrm{C}$, well within the hypothesized optimal range for P. bahamense var. bahamense. Similar explanations were applicable for the other occasions when $P$. bahamense var. bahamense was observed at temperatures $<20^{\circ} \mathrm{C}$. For ecosystems north of Florida Bay, observations of $P$. bahamense var. bahamense near or $<20^{\circ} \mathrm{C}$ were all confined to the fall season and were all closely preceded by periods of higher water temperatures. It is important to note that all of the ecosystems included in this study had warm-season temperatures that reached $30^{\circ} \mathrm{C}$ (Table $1)$, although the length of time during
Table 1. Pyrodinium bahamense var. bahamense. Number of samples with $P$. bahamense var. bahamense relative to the total number of samples analyzed (with P.b./total), years of observation (years obs.), maximum cell density (cell $\mathrm{ml}^{-1}$ ), salinity range of the samples, temperature range of samples $\left({ }^{\circ} \mathrm{C}\right)$, and estimate of average water retention index (RTI $-\mathrm{S}$ : short [days]; M: medium [weeks]; L: long [>weeks])

\begin{tabular}{|c|c|c|c|c|c|c|}
\hline Location & $\begin{array}{l}\text { With } \\
\text { P.b./ } \\
\text { total }\end{array}$ & $\begin{array}{l}\text { Years } \\
\text { obs. }\end{array}$ & $\begin{array}{c}\text { Max. } \\
\text { cell } \\
\text { density }\end{array}$ & $\begin{array}{c}\text { Salinity } \\
\text { range }\end{array}$ & $\begin{array}{l}\text { Temp } \\
\text { range }\end{array}$ & RTI \\
\hline \multicolumn{7}{|l|}{ St. Johns River } \\
\hline $4 \mathrm{~km}$ upstream & $0 / 34$ & 4 & 0 & $4-31$ & $10-30$ & $\mathrm{~S}$ \\
\hline $17 \mathrm{~km}$ upstream & $0 / 34$ & 4 & 0 & $<1-28$ & $10-30$ & $\mathrm{~S}$ \\
\hline $40 \mathrm{~km}$ upstream & $0 / 120$ & 11 & 0 & $<1-14$ & $9-31$ & $\mathrm{~S}-\mathrm{M}$ \\
\hline $\begin{array}{l}\text { Guana-Tolomato } \\
\text { River }\end{array}$ & $0 / 24$ & 2 & 0 & $13-35$ & $12-30$ & $\mathrm{~S}$ \\
\hline \multicolumn{7}{|l|}{ Matanzas River } \\
\hline St. Augustine & $0 / 24$ & 2 & 0 & $26-34$ & $12-30$ & $\mathrm{~S}$ \\
\hline Pelicer Creek & $0 / 24$ & 2 & 0 & $<1-27$ & $11-32$ & $\mathrm{~S}$ \\
\hline Ft. Matanzas & $1 / 24$ & 2 & 23 & $27-34$ & $12-30$ & $\mathrm{~S}$ \\
\hline Marineland & $0 / 24$ & 2 & 0 & $23-35$ & $13-30$ & $\mathrm{~S}$ \\
\hline Palm Coast & $0 / 24$ & 2 & 0 & $17-35$ & $13-31$ & $\mathrm{~S}$ \\
\hline \multicolumn{7}{|l|}{ Smith Creek } \\
\hline Flagler Beach & $0 / 24$ & 2 & 0 & $13-35$ & $13-31$ & $\mathrm{~S}$ \\
\hline \multicolumn{7}{|l|}{ Halifax River } \\
\hline Daytona & $0 / 24$ & 2 & 0 & $8-34$ & $14-31$ & $\mathrm{~S}-\mathrm{M}$ \\
\hline New Smyrna & $1 / 24$ & 2 & 168 & $6-34$ & $13-30$ & $\mathrm{~S}$ \\
\hline \multicolumn{7}{|l|}{ Mosquito Lagoon } \\
\hline Oak Hill & $7 / 48$ & 4 & 85 & $23-37$ & $13-31$ & M \\
\hline \multicolumn{7}{|l|}{ Indian River Lagoon } \\
\hline Titusville & $30 / 65$ & 8 & 638 & $16-39$ & $12-30$ & $\mathrm{~L}$ \\
\hline Banana River & $32 / 65$ & 8 & 566 & $10-31$ & $12-31$ & $\mathrm{~L}$ \\
\hline Eau Gallie & $20 / 65$ & 8 & 367 & $12-33$ & $14-31$ & $\mathrm{~L}$ \\
\hline Melbourne & $19 / 65$ & 8 & 776 & $7-37$ & $14-31$ & $\mathrm{~L}$ \\
\hline Sebastian & $6 / 30$ & 8 & 95 & $11-35$ & $14-31$ & $\mathrm{~S}-\mathrm{M}$ \\
\hline St. John Is. & $4 / 25$ & 8 & 13 & $14-37$ & $14-31$ & $\mathrm{M}$ \\
\hline Vero-Ft. Pierce & $1 / 29$ & 8 & 1 & $13-38$ & $14-31$ & $\mathrm{M}$ \\
\hline \multicolumn{7}{|l|}{ Florida Bay } \\
\hline West (Cape Sable) & $2 / 42$ & 4 & 1 & $26-38$ & $15-31$ & $\mathrm{~S}$ \\
\hline N. central (Rankin) & $18 / 42$ & 4 & 8 & $16-50$ & $16-31$ & $\mathrm{~L}$ \\
\hline S. central (Captain) & $20 / 42$ & 4 & 1 & $26-40$ & $16-31$ & M \\
\hline East (Bottle Key) & $34 / 38$ & 4 & 6 & $10-40$ & $16-31$ & $\mathrm{~L}$ \\
\hline \multicolumn{7}{|l|}{ Tampa Bay } \\
\hline Lower (near mouth) & $4 / 30$ & 1 & 14 & $24-33$ & $13-31$ & $\mathrm{~S}$ \\
\hline Middle & $4 / 30$ & 1 & 2 & $17-29$ & $13-31$ & $\mathrm{~S}$ \\
\hline Upper (Old Tampa) & $19 / 30$ & 1 & 380 & $15-27$ & $13-31$ & M-L \\
\hline \multicolumn{7}{|c|}{ Suwannee River estuary } \\
\hline North Reef (4 sites) & $0 / 192$ & 4 & 0 & $9-35$ & $8-32$ & $\mathrm{~S}$ \\
\hline South Reef (5 sites) & $0 / 240$ & 4 & 0 & $<1-33$ & $9-32$ & $\mathrm{~S}$ \\
\hline $\begin{array}{l}\text { Nearshore (5 sites) } \\
\text { north }\end{array}$ & $0 / 240$ & 4 & 0 & $15-37$ & $9-31$ & $\mathrm{~S}$ \\
\hline $\begin{array}{l}\text { Nearshore (8 sites) } \\
\text { south }\end{array}$ & $0 / 384$ & 4 & 0 & $15-37$ & $9-31$ & $\mathrm{~S}$ \\
\hline $\begin{array}{l}\text { Offshore shelf } \\
\quad(6 \text { sites })\end{array}$ & $0 / 288$ & 4 & 0 & $28-37$ & $10-31$ & $\mathrm{~S}$ \\
\hline Cedar Key (6 sites) & $0 / 288$ & 4 & 0 & $9-36$ & $9-32$ & $\mathrm{~S}$ \\
\hline
\end{tabular}




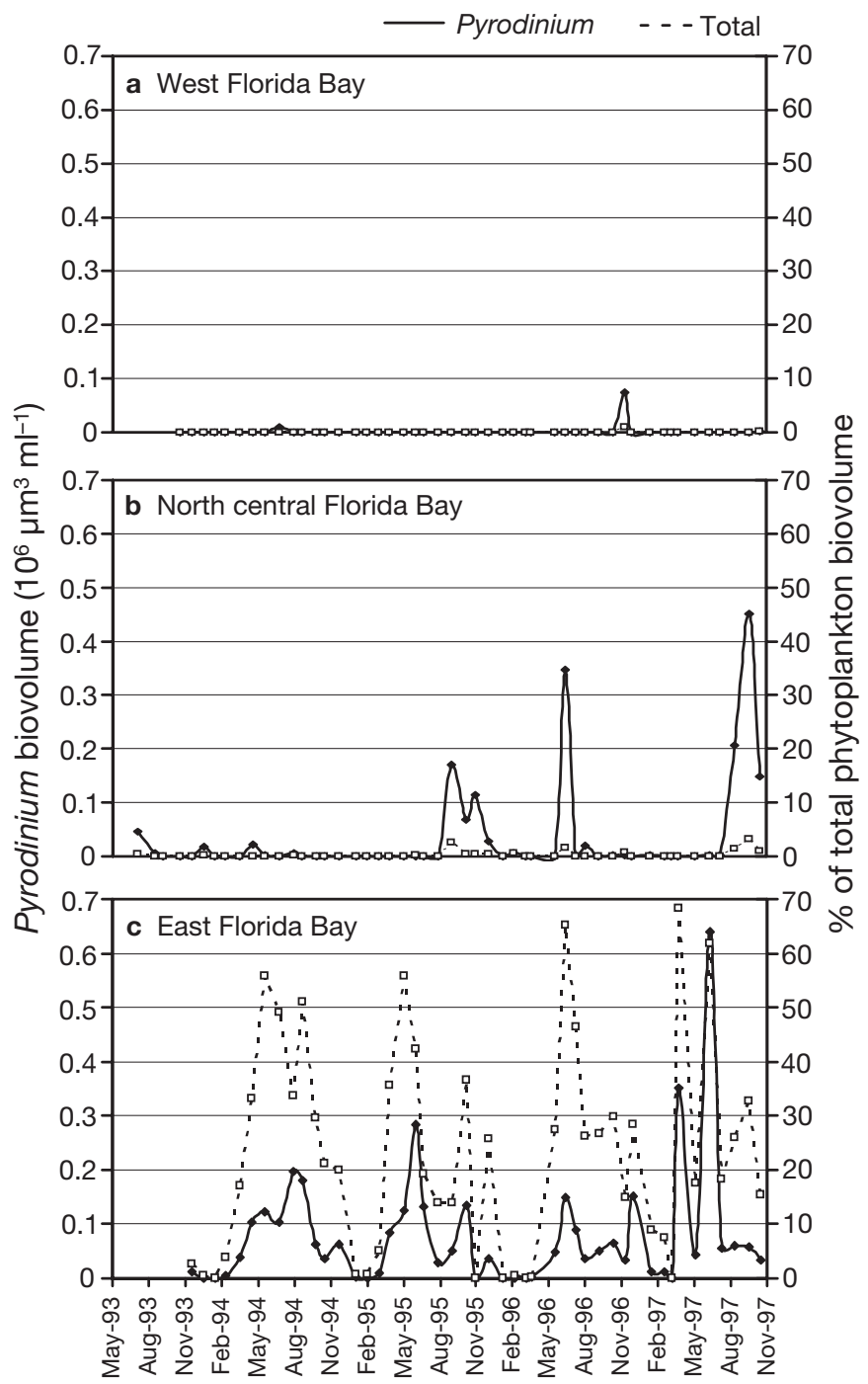

Fig. 2*. Pyrodinium bahamense var. bahamense. Biovolume at 3 representative sampling sites (a to c) in Florida Bay (left axis) and the relative percent of total phytoplankton biovolume represented by $P$. bahamense var. bahamense (right axis)

which temperatures exceeded $20^{\circ} \mathrm{C}$, as well as the lowest temperatures observed, were both lower at sites in the northern half of the Florida peninsula.

The prominence of Pyrodinium bahamense var. bahamense in a number of tidally restricted lagoons and bays in Florida suggested 2 additional factors for consideration in defining the basis for the distribution of the species: salinity and water residence times. The observations included in this study demonstrate that $P$. bahamense var. bahamense can tolerate a broad range of salinities. Within the 3 most flow-restricted regions included in this study (i.e. the northern Indian River Lagoon and the inner basins of Florida Bay and Tampa Bay), P. bahamense var. bahamense was observed at salinities from 14 to 46 and formed blooms over almost the same range, i.e. 16 to 42 (Fig. 7). However, a number of other sampling sites, with wide ranges in salinities, did not contain $P$. bahamense var. bahamense, including the St. Johns River estuary, the Guana-Tolomato River, the Halifax River, Smith Creek, the Suwannee River estuary, and most of the Matanzas River (Table 1).

In terms of water residence time, all of the regions associated with blooms of Pyrodinium bahamense var. bahamense were characterized by long residence times, including the northern region of the Indian River Lagoon and the inner reaches of Tampa Bay and Florida Bay. Conversely, P. bahamense var. bahamense was largely absent from regions noted for high tidal mixing rates and/or river flushing rates (Table 1).

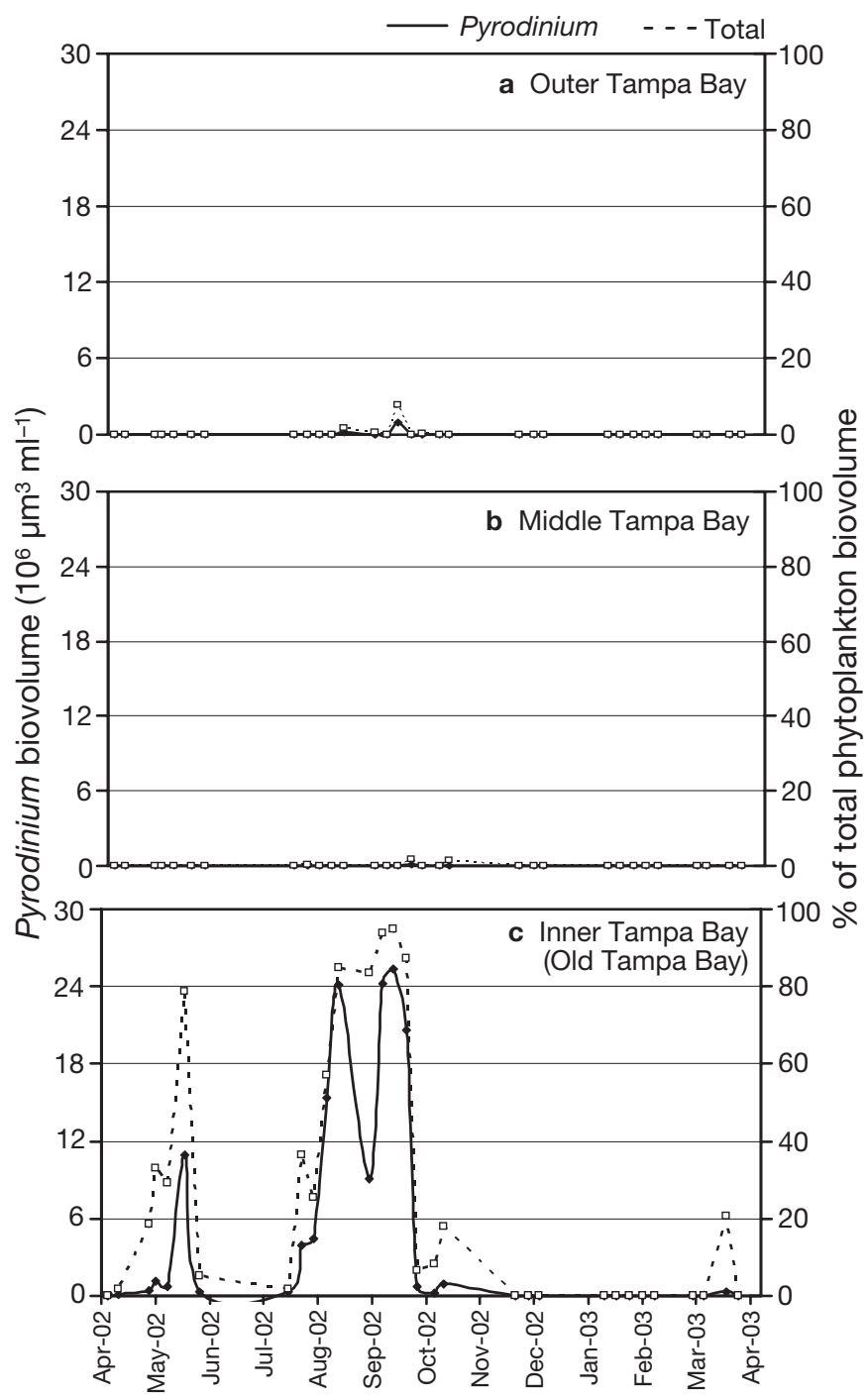

Fig. $3^{*}$. Pyrodinium bahamense var. bahamense. Biovolume at 3 representative sampling sites (a to c) in Tampa Bay (left axis) and the relative percent of total phytoplankton biovolume represented by $P$. bahamense var. bahamense (right axis) 
The exceptions to this pattern were the Matanzas and New Smyrna Inlets, where P. bahamense var. bahamense was observed on 1 date in 2001. These observations may be related to washout from more flowrestricted regions of the Matanzas and Halifax River Lagoons, respectively. This is supported by the fact that the observations were both in August of 2001, the beginning of a high rainfall period in northeast Florida.

Another factor that was considered in the control of Pyrodinium bahamense var. bahamense distribution was nutrient regime. In terms of total phosphorus, $P$. bahamense var. bahamense was observed in both the most oligotrophic reaches of eastern Florida Bay, with a mean total phosphorus concentration of $8 \mu \mathrm{gl}^{-1}$, and in the nutrient-rich Tampa Bay, where total phospho-

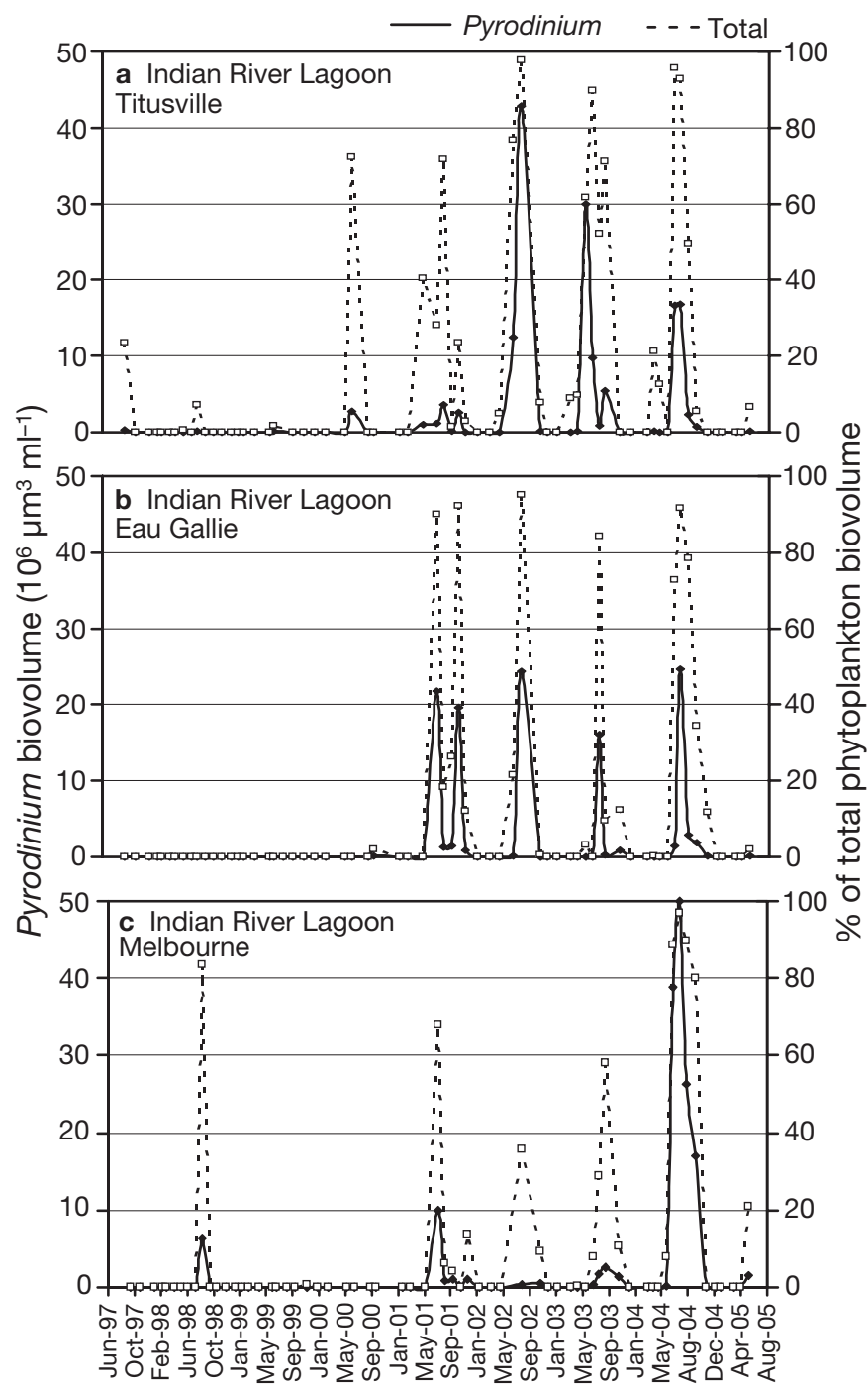

Fig. $4^{*}$. Pyrodinium bahamense var. bahamense. Biovolume at 3 representative sampling sites (a to $\mathrm{c}$ ) in the Indian River Lagoon (left axis) and the relative percent of total phytoplankton biovolume represented by $P$. bahamense var. bahamense (right axis)

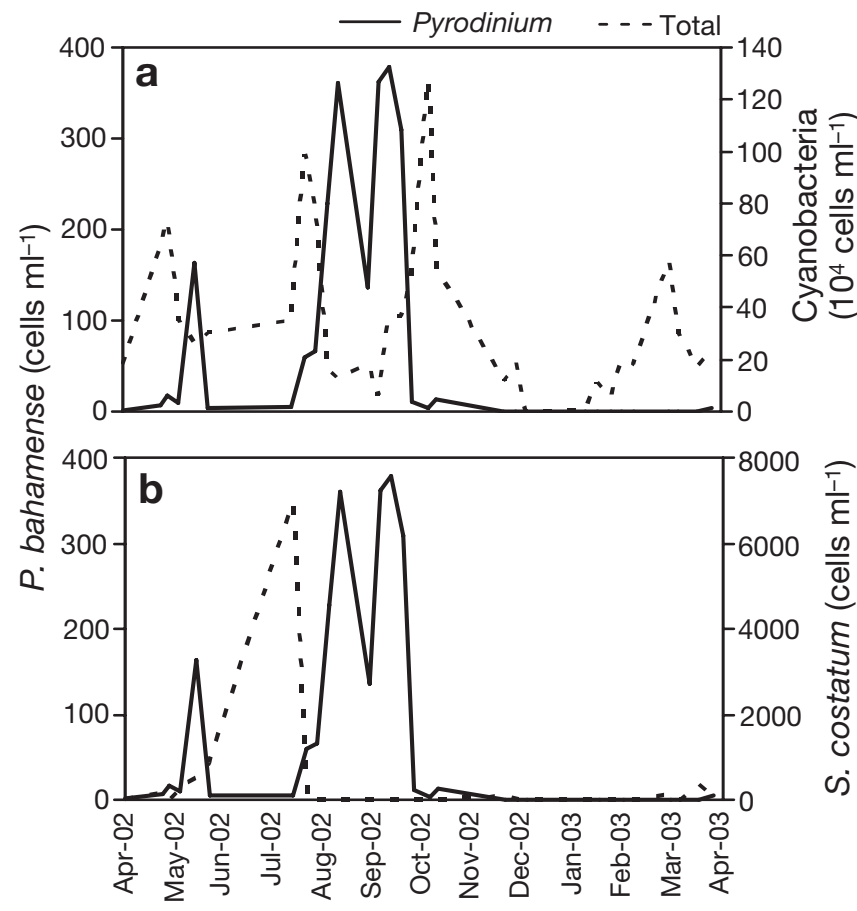

Fig. 5. Pyrodinium bahamense var. bahamense. A comparison of the temporal patterns of $P$. bahamense var. bahamense (a \& b, solid line) abundance with cyanobacterial picoplankton abundance (a, dashed line) and Skeletonema costatum abundance ( $b$, dashed line) in Tampa Bay (after Badylak et al. 2006)

rus concentrations regularly exceed $100 \mu \mathrm{g} \mathrm{l}^{-1}$ (Table 2 , Fig. 8). In the Indian River Lagoon, P. bahamense var. bahamense was observed at bloom levels over a wide range of total phosphorus concentrations (Fig. 8), but was not prominently represented in the most phosphorus-rich region of the lagoon between Sebastian and Ft. Pierce, where total phosphorus concentrations ranged up to $330 \mathrm{\mu g} \mathrm{l}^{-1}$. The relationship between total phosphorus concentration and overall $P$. bahamense var. bahamense abundance was therefore weak. However, there was a relationship between peak abundances (i.e. $>100$ cells $\mathrm{ml}^{-1}$ ) and total phosphorus concentrations (Fig. 9). In Tampa Bay there was no apparent relationship between total phosphorus and $P$. bahamense var. bahamense abundance, although the highest cell densities were observed at TP concentrations $>100 \mu \mathrm{g} \mathrm{l}^{-1}$. The latter observation is related to the fact that TP concentrations during the sampling period were highest in Old Tampa Bay during the summer, coincident with the location and timing of $P$. bahamense var. bahamense blooms.

The relationship between total nitrogen and Pyrodinium bahamense var. bahamense abundance was somewhat less defined than the relationship with total phosphorus. As in the case of phosphorus, P. bahamense var. bahamense was observed over a wide range of 


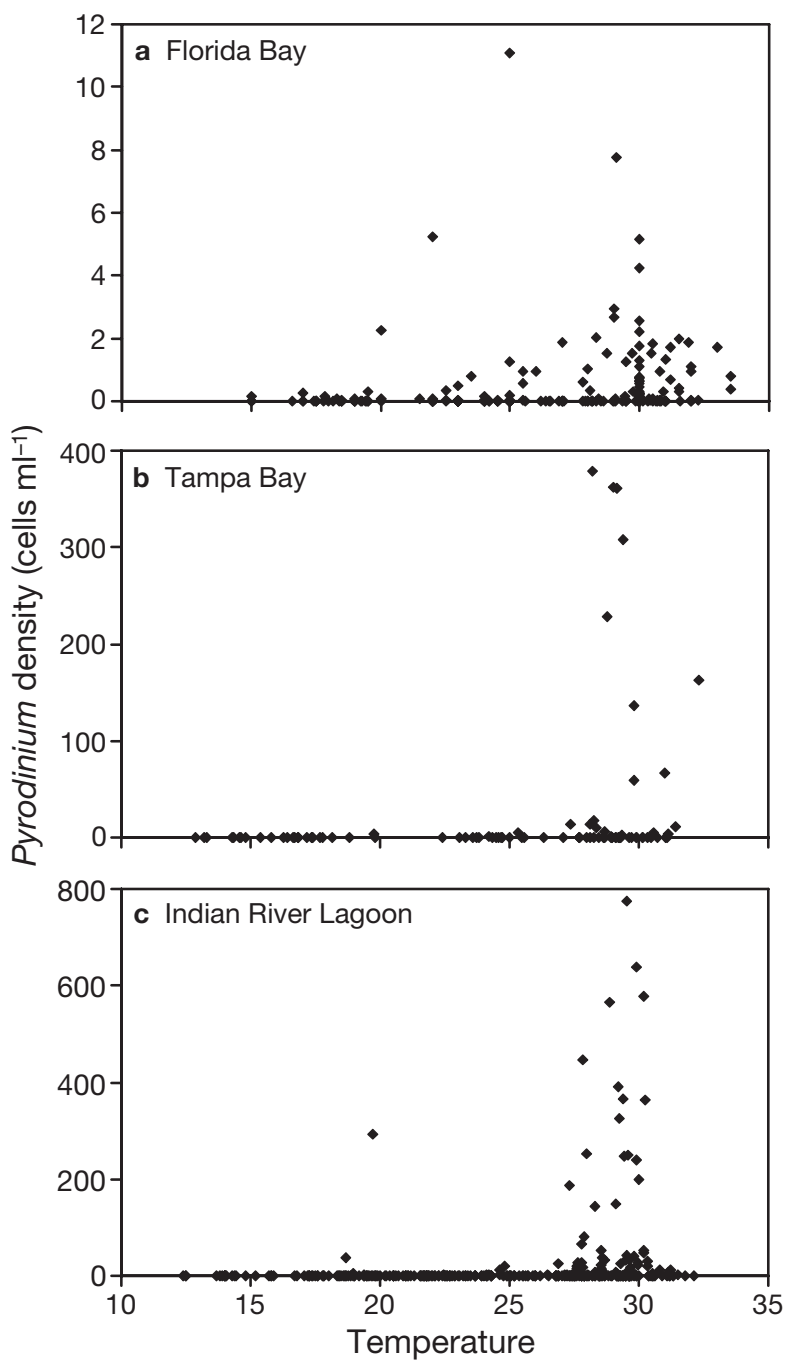

Fig. 6. Pyrodinium bahamense var. bahamense. Relationship between temperature and $P$. bahamense var. bahamense density in (a) Florida Bay, (b) Tampa Bay, and (c) Indian River Lagoon

total nitrogen concentrations in the Indian River Lagoon, Tampa Bay, and Florida Bay (Fig. 10). In the Indian River Lagoon and Florida Bay, peak abundances appeared to increase with total nitrogen concentration (Fig. 10), despite the lack of a strong overall relationship between abundance and total nitrogen concentration. In Tampa Bay, there appeared to be a threshold total nitrogen concentration for the occurrence of $P$. bahamense var. bahamense of about $600 \mathrm{\mu g} \mathrm{l}^{-1}$ (Fig. 10), similar to the threshold phenomena observed for total phosphorus, for analogous reasons.

From a broader perspective, there was no clear trend among the sampling regions in the mean total nitrogen, total phosphorus, or TN/TP ratios that were associated with Pyrodinium bahamense var. bahamense (Table 2). In the 3 ecosystems where $P$. bahamense var. bahamense was most prominent (Florida Bay, Tampa

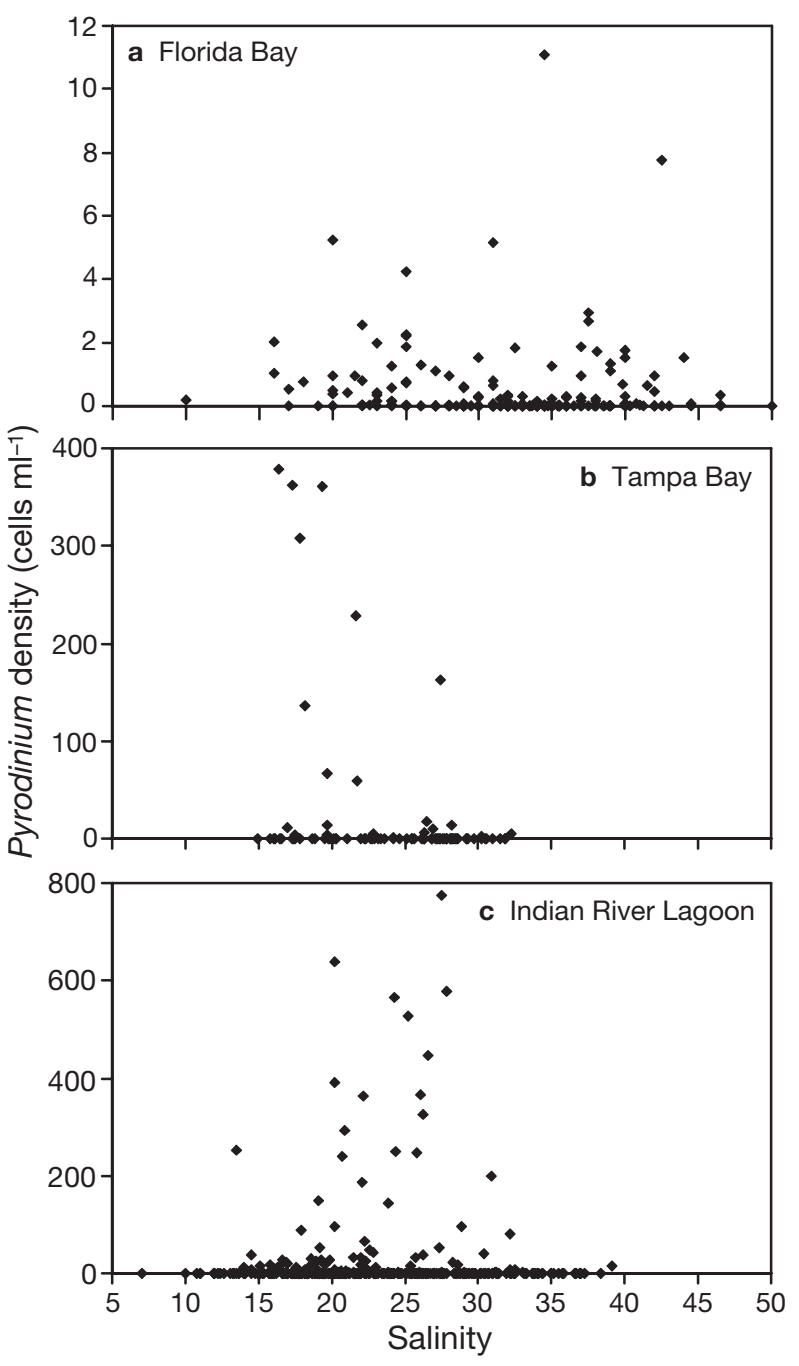

Fig. 7. Pyrodinium bahamense var. bahamense. Relationship between salinity and $P$. bahamense var. bahamense density in (a) Florida Bay, (b) Tampa Bay, and (c) Indian River Lagoon

Bay, and Indian River Lagoon), mean TN concentrations ranged from 567 to $1532 \mu \mathrm{g} \mathrm{l}^{-1}$, mean TP concentrations ranged from 8 to $100 \mu \mathrm{g} \mathrm{l}^{-1}$, and TN/TP ratios ranged from 6.5 to 116.7 . Similar ranges for these parameters were observed in ecosystems where $P$. bahamense var. bahamense was seldom observed (Tables 1 \& 2), although the exceptionally high TN/TP ratios and low TP values observed in Florida Bay were unique to that ecosystem.

In a further effort to examine possible linkages between Pyrodinium bahamense var. bahamense abundance and key environmental variables, CCA was applied to a combined data set from Florida Bay, Indian River Lagoon, and Tampa Bay. The relationships between $P$. bahamense var. bahamense biomass (cell density and relative abundance) and both water residence time and total phosphorus concentration were 
Table 2. Total nitrogen $\left(\mathrm{TN}, \mu g \mathrm{l}^{-1}\right)$, total phosphorus (TP, $\mu \mathrm{g}^{-1}$ ) and TN:TP ratios at the major sites included in this study. Mean values are shown

\begin{tabular}{|c|c|c|c|}
\hline Location & TN (range) & TP (range) & TN:TP \\
\hline \multicolumn{4}{|l|}{ St. Johns River } \\
\hline $4 \mathrm{~km}$ upstream & 679 (350-1030) & $129(73-233)$ & 5.5 \\
\hline $17 \mathrm{~km}$ upstream & $1020(460-1530)$ & $150(84-297)$ & 7.1 \\
\hline $40 \mathrm{~km}$ upstream & $1110(390-1027)$ & $130(48-274)$ & 9.2 \\
\hline \multicolumn{4}{|l|}{ Guana-Tolomato } \\
\hline River & $592(390-1027)$ & $81(21-151)$ & 8.5 \\
\hline \multicolumn{4}{|l|}{ Matanzas River } \\
\hline St. Augustine & $447(267-951)$ & $68(20-113)$ & 7.2 \\
\hline Pelicer Creek & $711(308-1951)$ & $91(17-196)$ & 9.0 \\
\hline Ft. Matanzas & $370(203-1198)$ & $50(13-86)$ & 8.4 \\
\hline Marineland & $357(140-869)$ & $44(7-107)$ & 9.6 \\
\hline Palm Coast & $398(40-860)$ & $50(11-107)$ & 8.5 \\
\hline \multicolumn{4}{|l|}{ Smith Creek } \\
\hline Flagler Beach & $574(184-1041)$ & $84(33-168)$ & 7.3 \\
\hline \multicolumn{4}{|l|}{ Halifax River } \\
\hline Daytona & $675(55-1160)$ & $116(28-200)$ & 7.2 \\
\hline New Smyrna & $361(55-1160)$ & $39(14-76)$ & 9.8 \\
\hline \multicolumn{4}{|l|}{ Mosquito Lagoon } \\
\hline Oak Hill & $634(216-1240)$ & $57(17-101)$ & 11.8 \\
\hline \multicolumn{4}{|l|}{ Indian River Lagoon } \\
\hline Titusville & 945 (386-1495) & $43(5-110)$ & 27.4 \\
\hline Banana River & 1019 (107-1685) & $55(5-116)$ & 23.3 \\
\hline Eau Gallie & $826(275-1386)$ & $57(20-128)$ & 16.6 \\
\hline Melbourne & $780(252-1451)$ & $66(20-159)$ & 13.2 \\
\hline Sebastian & $445(102-899)$ & $57(25-145)$ & 9.0 \\
\hline St. John Is. & $543(81-1020)$ & $96(27-335)$ & 6.9 \\
\hline Vero-Ft. Pierce & $547(178-1107)$ & $84(25-202)$ & 8.5 \\
\hline \multicolumn{4}{|l|}{ Florida Bay } \\
\hline West (Cape Sable) & $405(193-713)$ & $24(9-105)$ & 25.9 \\
\hline N. central (Rankin) & $1532(355-3298)$ & $28(4-81)$ & 94.1 \\
\hline S. central (Captain) & 706 (311-1724) & $12(3-38)$ & 101.6 \\
\hline East (Bottle Key) & $739(430-1167)$ & $8(2-26)$ & 116.7 \\
\hline \multicolumn{4}{|l|}{ Tampa Bay } \\
\hline Lower (near mouth) & $380(182-832)$ & $87(24-187)$ & 5.3 \\
\hline Middle & $419(218-660)$ & $95(34-132)$ & 5.0 \\
\hline Upper (Old Tampa) & $567(260-886)$ & $106(29-182)$ & 6.5 \\
\hline \multicolumn{4}{|c|}{ Suwannee River estuary } \\
\hline North Reef (4 sites) & $500(110-1300)$ & $50(20-630)$ & 10.0 \\
\hline South Reef (5 sites) & $540(160-1000)$ & $60(10-410)$ & 9.0 \\
\hline $\begin{array}{l}\text { Nearshore (5 sites) } \\
\text { north }\end{array}$ & $330(30-790)$ & $25(10-80)$ & 13.2 \\
\hline $\begin{array}{l}\text { Nearshore (8 sites) } \\
\text { south }\end{array}$ & $280(40-190)$ & $22(10-150)$ & 12.7 \\
\hline $\begin{array}{l}\text { Offshore shelf } \\
\text { (6 sites) }\end{array}$ & $160(10-360)$ & $15(5-80)$ & 10.7 \\
\hline Cedar Key (6 sites) & $370(60-890)$ & $40(30-180)$ & 9.3 \\
\hline
\end{tabular}

salinities (Fig. 11). As the temperature threshold for Pyrodinium blooms was observed to be approximately $25^{\circ} \mathrm{C}$, we limited the CCA analysis to temperatures $>25^{\circ} \mathrm{C}$. Therefore, the effect of temperature on Pyrodinium abundance was limited, and no significant correlations were observed.

The first 2 canonical axes explained $31.2 \%$ of the cumulative variance for Pyrodinium abundance. The top 2 environmental factors that correlated significantly $(\mathrm{p}<0.05)$ with Canonical Axis 1 included: the RTI $(r=0.62)$ and salinity $(r=-0.76)$. The environmental factor that correlated significantly $(\mathrm{p}<0.05)$ with Canonical Axis 2 was TP $(\mathrm{r}=-0.60)$. Monte Carlo permutation tests showed that the first 2 canonical axes were significant (eigenvalue $=0.006$, $\mathrm{p}<0.05$ and eigenvalue $=0.001, \mathrm{p}<0.05$, respectively).

\section{DISCUSSION}

The environmental factors that dictate the distribution and dynamics of phytoplankton taxa have been extensively discussed in the literature (Margalef 1978, Margalef et al. 1979, Smayda 1980, 1997, 2002, Sournia 1982, Paerl 1988, Reynolds 1988, 1995, Hallegraeff 1993, Reynolds \& Smayda 1998, Smayda \& Reynolds 2001). For the purpose of this discussion, it is useful to consider these factors from 3 different perspectives: (1) inherent ecophysiological limitations for survival and reproduction, (2) environmental regulation of growth and standing crop potential, and (3) competition with other taxa.

\section{Ecophysiological limitations}

The first category of environmental factors that can affect the success of Pyrodinium bahamense var. bahamense are those that relate to the inherent physiological limitations of the alga, in terms of survival and reproductive success. Within this category, temperature appears to be a key

corroborated with CCA (Fig. 11). Centroids of Pyrodinium (density and relative abundance) were located closer to the right side of the diagram, corresponding to a longer water retention time (RTI), higher than average total phosphorus, and lower than average factor dictating presence and absence. P. bahamense has long been regarded as a tropical species, given its prominence in the Indo-Pacific (Maclean 1989, Azanza \& Taylor 2001) and Caribbean regions of the North Atlantic (Plate 1907, Margalef 1961, Steidinger 


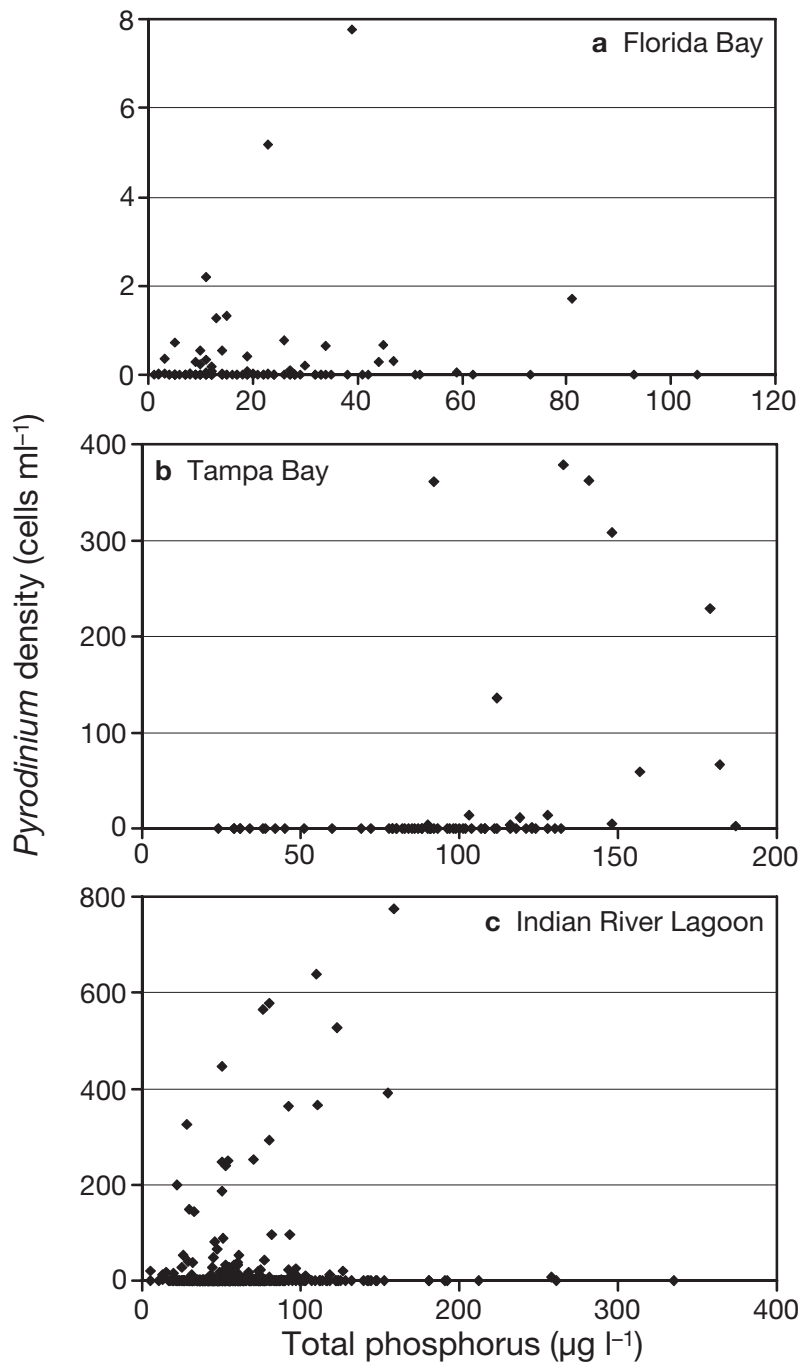

Fig. 8. Pyrodinium bahamense var. bahamense. Relationship between total phosphorus and $P$. bahamense var. bahamense density in (a) Florida Bay, (b) Tampa Bay, and (c) Indian River Lagoon

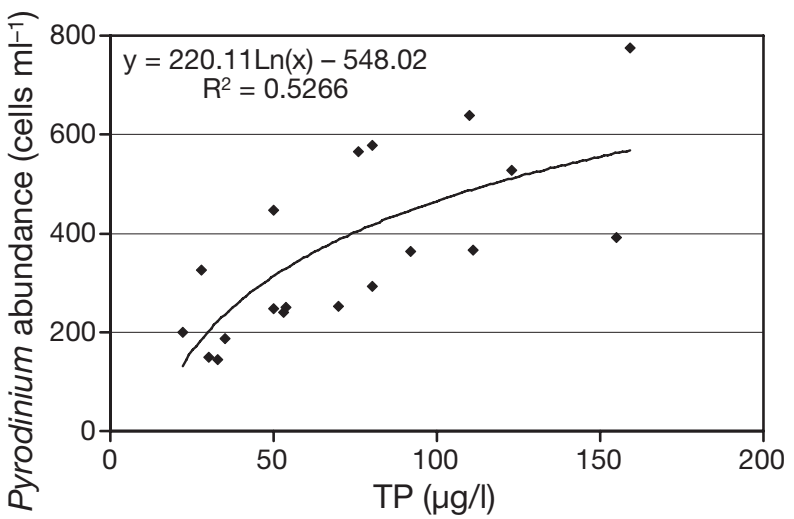

Fig. 9. Pyrodinium bahamense var. bahamense. Regression relationship between total phosphorus (TP) and $P$. bahamense var. bahamense densities under bloom conditions ( $>100$ cells $\mathrm{ml}^{-1}$ ) in the Indian River Lagoon
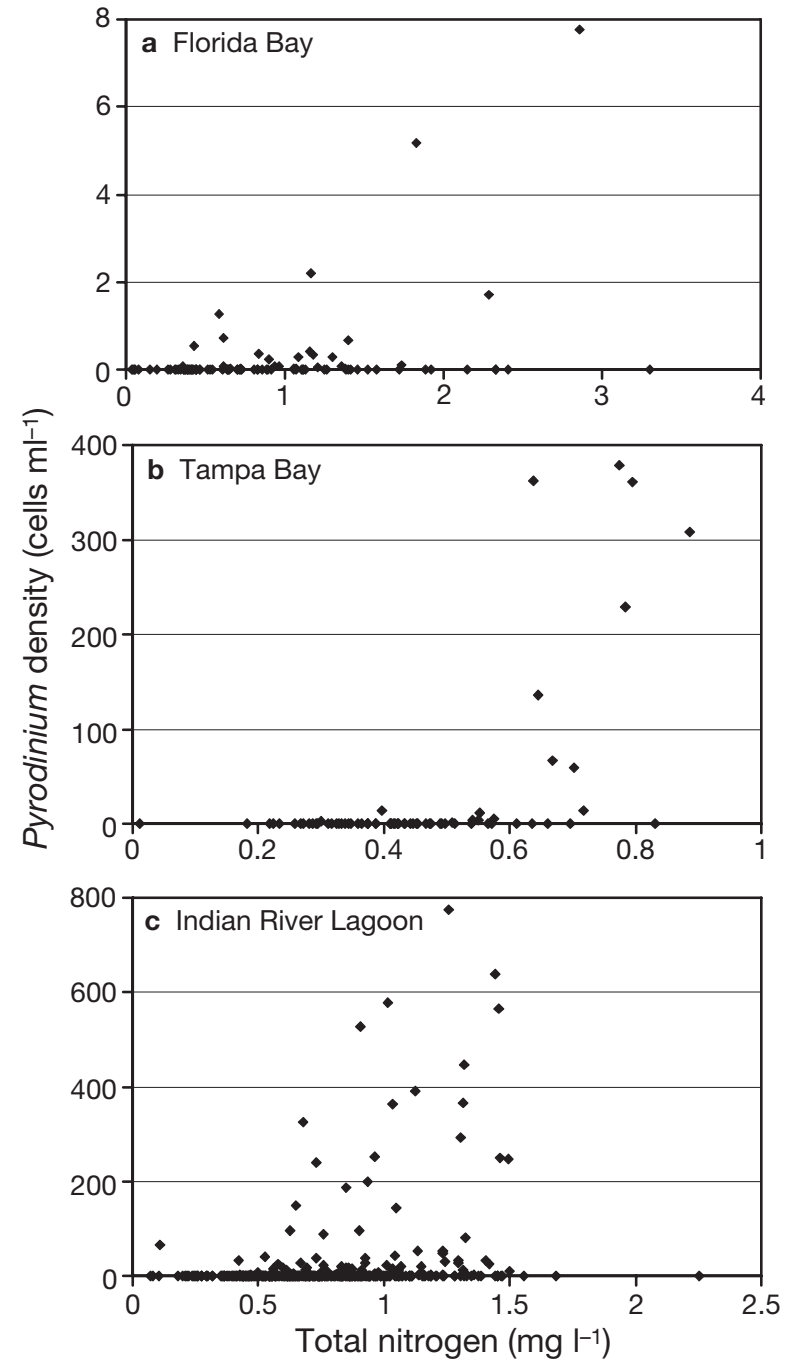

Fig. 10. Pyrodinium bahamense var. bahamense. Relationship between total nitrogen and $P$. bahamense var. bahamense density in (a) Florida Bay, (b) Tampa Bay, and (c) Indian River Lagoon

et al. 1980, Balech 1985, Phlips et al. 2004a, Badylak et al. 2004) and apparent absence at higher latitudes. The results of the present study support the importance of temperature as a limiting factor for the distribution of $P$. bahamense var. bahamense. However, on the Florida peninsula $P$. bahamense var. bahamense is not limited to the tropical/sub-tropical habitats of Florida Bay, where it occurs nearly year-round, but extends into the subtropical/warm temperate regions of central and northern Florida, where vegetative cells appear in the water column in the warm season, when temperatures exceed $20^{\circ} \mathrm{C}$.

The actual biogeographical northern boundary for Pyrodinium bahamense var. bahamense is difficult to define with the information currently available. In terms of temperature alone, it is likely that the bound- 


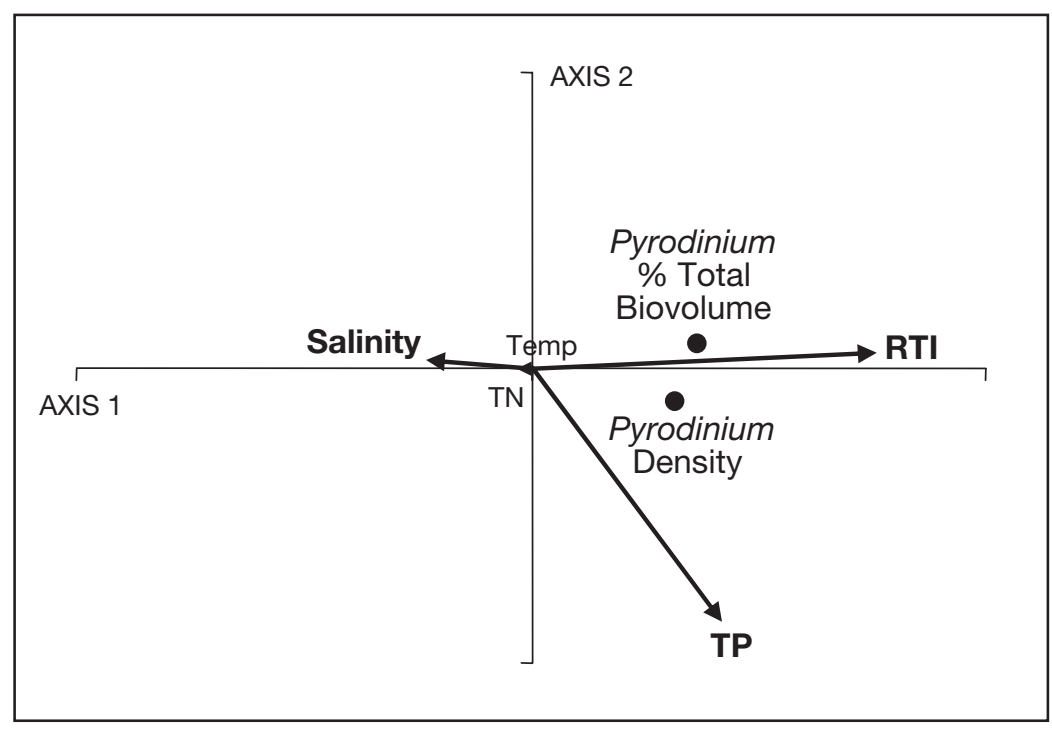

Fig. 11. Pyrodinium bahamense var. bahamense. Results of canonical correspondence analysis for the relationships between 2 measures of importance of $P$. var. bahamense cell density and relative abundance (\% of total phytoplankton biovolume), and 5 environmental variables, salinity, temperature, total phosphorus (TP), total nitrogen (TN), and water retention time index (RTI). The data used were restricted to temperatures $>25^{\circ} \mathrm{C}$, since this appears to be a threshold level for the significant presence of the species. The length of the variable arrows is proportional to the rate of change for that variable

Tampa Bay and the Indian River Lagoon. Similar observations have been made for $P$. bahamense var. compressum in the Indo-Pacific region, where a linkage has been made between rainfall-induced mesohaline conditions and blooms (Azanza \& Taylor 2001), although the minimum salinity for growth in culture has been reported to be between 16 and 20 (Usup \& Azanza 1998).

Beyond the general trends in salinity and temperature tolerance indicated by the aforementioned empirical correlations, the scarcity of experimental data on the physiological limitations of Pyrodinium bahamense var. bahamense preclude more definitive conclusions about its potential range. Similarly, in terms of absolute growth requirements, the minimal nutrient and light requirements for the survival and reproduction of $P$. bahamense var. bahamense have not been specifically defined. It clearly flourishes in shallow, light-rich coastal ecosystems subject to significant nutrient loads, such as the

ary extends beyond Florida, given the warm summer water temperatures in the northern Gulf of Mexico and coastal regions of Georgia and the Carolinas, despite the fact that $P$. bahamense has not yet been reported for these regions. For example, $P$. bahamense has not been reported for coastal ecosystems in the northern Gulf of Mexico along the panhandle of Florida, including Perdido Bay, Escambia Bay, Pensacola Bay, Chocktawhatchee Bay, and Apalachee Bay (Livingston 2001, Murrel \& Lores 2004), despite water temperatures in excess of $25^{\circ} \mathrm{C}$ from the spring through early fall. The absence of reports of $P$. bahamense in these regions could be attributable to a shortage of observational information for certain areas, as well as the lack of appropriate habitat or seed banks of viable cysts.

Another obvious factor for consideration is salinity tolerance. The salinity range over which Pyrodinium bahamense var. bahamense was observed in this study indicates that 10 may be near the lower limit of its tolerance, while the upper limit extends at least to a salinity of 45 . The fact that Pyrodinium not only appears over such a broad range of salinities, but has been observed at bloom concentrations over nearly the same range, demonstrates its euryhaline character. This observation helps to explain the success of $P$. bahamense var. bahamense in Florida ecosystems subject to large and variable inputs of freshwater, such as
Indian River Lagoon and Tampa Bay. By contrast, it is also a prominent feature of the phytoplankton community in the phosphorus-limited eastern region of Florida Bay, although it does not reach bloom concentrations, likely due to limited nutrient availability. Clearly, $P$. bahamense var. bahamense is capable of surviving in environments of varying inorganic phosphorus concentrations.

Other important factors in the success of Pyrodinium bahamense var. bahamense are the benthic habitat requirements for the survival and germination of resting spores (Anderson 1989, Villanoy et al. 1996, Sombrito et al. 2004). The prominence of the species in flow-restricted portions of shallow estuaries with organically enriched sediments, such as the Indian River Lagoon and Tampa Bay, indicates that these types of benthic habitat can be favorable for the survival and eventual germination of resting cells. The prominence of $P$. bahamense var. bahamense in eastern Florida Bay, which is characterized by a thin layer of organically poor, calcium-carbonate-rich sediments, manifests the flexibility of resting cells to a range of sediment conditions. It is possible that the depth of an ecosystem, rather than specific sediment types, may be a factor in the success of $P$. bahamense var. bahamense, particularly as it relates to light availability and the potential for wind-induced resuspension of cysts (Anderson 1989, Villanoy et al. 1996, Sombrito et al. 2004). 


\section{Environmental regulation of growth and standing crop}

The second category of environmental factors that can effect the success of Pyrodinium bahamense var. bahamense includes those that influence productivity and standing crop potential. These factors directly or indirectly affect the gain and loss processes associated with the dynamics of phytoplankton standing crops, such as water residence time, flushing rates, light availability, nutrient availability, temperature, grazing, and sedimentation. The potential importance of water residence time is indicated by the observation that all of the estuarine habitats in Florida where $P$. bahamense var. bahamense dominate the phytoplankton community, and/or formed blooms, are characterized by long residence times, including the northern Indian River Lagoon and the inner basins of Florida Bay and Tampa Bay. The role of residence time in defining the standing crop potential of $P$. bahamense var. bahamense is supported by the results of CCA, which identifies a strong relationship between abundance and residence time. The latter relationship may, in part, be a consequence of the relatively low maximum growth rates reported for the species (Seliger et al. 1970), placing it at a disadvantage in short residence time ecosystems, relative to faster growing taxa.

Conversely, Pyrodinium bahamense var. bahamense was absent or occurred at low concentrations in regions of short residence time, such as the outer regions of Tampa Bay and Florida Bay, the Suwannee estuary, and the St. Johns River, as well as regions of the Guana River, Tolomato River, Matanzas River, and Indian River Lagoon near inlets to the Atlantic Ocean. Margalef (1961) similarly noted that blooms of $P$. bahamense in Puerto Rico are generally confined to Phosphorescent Bay, a region characterized by long water residence times. By contrast, P. bahamense var. bahamense is either absent, or present at low concentrations, in habitats of shorter water residence time along the coast of Puerto Rico. Short residence times can be associated with open, unrestricted coastal waters subject to high rates of tidal mixing or embayments with large inputs of water from major rivers. The St. Johns and Suwannee River estuaries, as well as many of the estuaries in the northern Gulf of Mexico (Livingston 2001, Murrel \& Lores 2004), fall into the latter category.

Another factor that may directly affect the abundance of Pyrodinium bahamense var. bahamense is nutrient availability. In this study, the 2 regions with the highest $P$. bahamense var. bahamense abundances, the northern Indian River Lagoon and the inner basin of Tampa Bay, are both characterized by high total phosphorus and total nitrogen concentrations (Phlips et al. 2002, 2004b, Badylak et al. 2006).
While there is little doubt that the availability of bioavailable nutrients is an essential component of biomass potential, there are questions about the relative importance of nutrient limitation of phytoplankton growth in such ecosystems relative to other factors, such as water residence time or light availability. The results of canonical analysis suggest that a relationship exists between total phosphorus and $P$. bahamense var. bahamense abundance, although the relationship is not as strong as with residence time.

The relatively long phytoplankton record available for the Indian River Lagoon provides an opportunity to examine the relationship between nutrient concentration and Pyrodinium bahamense var. bahamense abundance in greater detail. While the overall relationships between $P$. bahamense var. bahamense abundance and the 2 major nutrient elements for phytoplankton growth, phosphorus and nitrogen, are weak, there is a relatively strong regression relationship between total phosphorus concentration and $P$. bahamense var. bahamense abundance during major blooms, defined as concentrations of $>100$ cells $\mathrm{ml}^{-1}$. The importance of phosphorus availability for algal growth in the northern Indian River Lagoon is supported by the results of recent bioassay research, which indicate the potential for phosphorus limitation of phytoplankton growth in the northern Indian River Lagoon, particularly in the summer (Phlips et al. 2002). It may seem unusual that phytoplankton biomass in saltwater ecosystems with high total phosphorus concentrations, such as the Indian River Lagoon, could be phosphorus limited, but it is important to recognize that soluble reactive phosphorus (SRP) concentrations can reach low levels (i.e. $<5 \mu \mathrm{g} \mathrm{l}^{-1}$ ) during the summer bloom season, despite high total phosphorus levels.

The role of phosphorus availability in the control of the Pyrodinium bahamense var. bahamense bloom potential in the Indian River Lagoon is further indicated by the observation that most of the major blooms within the $8 \mathrm{yr}$ study period coincided with the period of elevated rainfall from the summer of 2001 through 2004, during which total phosphorus levels in the region were enhanced (Phlips et al. 2004a, b). The positive role of the rainfall-induced nutrient load from terrestrial watersheds in the formation of coastal Pyrodinium blooms has previously been suggested as an important process in the Indo-Pacific (Azanza \& Taylor 2001). Azanza \& Taylor (2001) suggest that blooms of $P$. bahamense var. compressum are frequently associated with El Niño periods of elevated rainfall. The temporal patterns of $P$. bahamense var. bahamense blooms observed in the Indian River Lagoon appear to support this hypothesis.

It has also been suggested that the release of humic substances from nearshore plant communities, such as 
mangroves, may be favorable for Pyrodinium bahamense var. bahamense (Usup \& Azanza 1998). Whether this enhancement is related to nutrient availability or some other processes remains to be definitively resolved. Within the scope of the present study, some of the ecosystems where $P$. compressum var. bahamense was observed are closely associated with mangroves, such as eastern and north-central Florida Bay. But the presence of mangroves is not a good predictor of $P$. bahamense var. bahamense abundance in Florida, as indicated by the general scarcity of the species in western and southern Florida Bay, despite extensive mangrove populations.

\section{Competitive strategies}

While the importance of long water residence times and nutrient availability in promoting high phytoplankton standing crops in coastal ecosystems is well established (Monbet 1982, Paerl 1988, Knoppers et al. 1991, Richardson \& Jørgensen 1996), it does not explain the specific reasons why Pyrodinium bahamense dominates certain blooms, as opposed to other species known to reach bloom proportions in the same regions at other times, such as the cyanobacterium Synechocystis in the Indian River Lagoon and Tampa Bay (Badylak et al. 2004, 2006), or Synechococcus in Florida Bay (Phlips et al. 1999). In order to address the latter question it is necessary to examine the factors that drive succession and other spatial or temporal variations in phytoplankton composition (Smayda 1989, 2002, Reynolds \& Smayda 1998, Smayda \& Reynolds 2001). This level of control focuses on attributes that provide $P$. bahamense var. bahamense with a competitive advantage over other species common to shallow warm-water ecosystems with long water residence time.

The results of this study reveal that Pyrodinium bahamense var. bahamense is capable of attaining a position of dominance (i.e. relative abundance) in a broad range of environments, from nutrient-poor to nutrient-rich habitats, and over a wide range of salinities. Given sufficient nutrient availability, it can form extensive blooms, which, due to its toxicity, can have significant implications for the structure of impacted ecosystems and, potentially, for human health (Landsberg 2002, Landsberg et al. 2002). The single unifying theme in the success of $P$. bahamense var. bahamense that arises from observations in Florida is that mixed salinities, shallow depths, and long water residence times are characteristic of all of the environments where $P$. bahamense var. bahamense is found in significant numbers. We forward 3 hypotheses that tie these observations to the issue of competitive strategies: (1) the euryhaline character of $P$. bahamense var. baha- mense allows it to out compete more stenohaline taxa in ecosystems with temporally variable salinity regimes, (2) the toxin-producing capability of $P$. bahamense var. bahamense reduces top-down control of standing crop potential, and (3) the relatively slow growth rates of $P$. bahamense var. bahamense may preclude it from competing successfully with fastergrowing phytoplankton in environments with short water residence times and/or persistent high nutrient loading rates. Conversely, large size and motility may provide $P$. bahamense var. bahamense with an ability to search for and store nutrients in more stable water columns, when the supply of new inorganic nutrients is more restricted or episodic.

In terms of the first hypothesis, the broad range of salinities over which Pyrodinium bahamense var. bahamense occurs in Florida (i.e. 10 to 45) demonstrates the euryhaline character of the species and undoubtedly provide it with a selective advantage over more stenohaline taxa, particularly in estuarine environments subject to rapid and substantial shifts in salinity. This attribute helps to explain the observed ability of $P$. bahamense var. bahamense to form blooms during high rainfall periods, in the flow-restricted regions of the Indian River Lagoon, Tampa Bay, and Florida Bay, during which salinities can drop rapidly. However, $P$. bahamense var. bahamense is not alone in its tolerance to salinity variation. For example, certain species of cyanobacterial picoplankton and small-celled diatoms, like Skeletonema costatum and Pseudo-nitzschia, have been shown to exhibit a wide range of tolerance to salinity (Rijstenbil 1988, Phlips et al. 1989, 2004a). As might be expected, the latter taxa have been observed to form blooms in many of the same regions of Florida subject to $P$. bahamense var. bahamense blooms, including the Indian River Lagoon (Badylak et al. 2004, Phlips et al. 2004a), Tampa Bay (Badylak et al. 2006), and Florida Bay (Phlips et al. 1999). This observation mandates further exploration of other factors that allow the large, motile, but slow-growing $P$. bahamense var. bahamense to dominate over faster-growing phytoplankton.

One of the most striking features of Pyrodinium bahamense var. bahamense that sets it apart from many of its potential euryhaline competitors is the ability to produce saxitoxin, a powerful neurotoxin (Landsberg et al. 2002). It has been suggested that top-down control of populations of toxic algae may be diminished by the inhibition of grazing activity attributable to the presence of toxins (Turner \& Tester 1997). The importance of differential grazing inhibition may be accentuated in estuarine habitats subject to long water residence times, because such bodies of water have the potential for generating higher zooplankton concentrations than rapidly flushed systems, due to the 
growth-rate limitations of many zooplankton. A similar argument could be made for benthic filter-feeding macroinvertebrates, which can be very abundant in shallow estuarine habitats and may selectively avoid consumption of toxic algae (Shumway 1990). However, the role of algal toxins in the control of grazing is variable and often species specific (Turner et al. 1998); therefore, it is not possible to estimate the relative importance of this phenomenon in $P$. bahamense var. bahamense dynamics without further information.

Given the difficulty of defining the relative importance of either salinity tolerance or toxicity to the success of Pyrodinium bahamense var. bahamense, it is important to extend the discussion into the broader realm of resource and habitat competition. The relationships between $P$. bahamense var. bahamense and the environment observed in this study generally fit, with some caveats, into the model of phytoplankton succession described by Margalef in the Mandala model (Margalef 1978, Margalef et al. 1979) and later revised by Reynolds \& Smayda (Reynolds \& Smayda 1998, Smayda \& Reynolds 2001), including the concepts presented as the Intaglio and C-S-R life-form strategies. Margalef argues in the Mandala model that the primary forces driving the success of dinoflagellates can be viewed on 2 environmental axes, turbulence and nutrient availability (Margalef et al. 1979). On the turbulence axis, dinoflagellates are favored by low turbulence and stratified water columns due to their intolerance to the physical stress of mixing, as opposed to better adapted taxa, like diatoms (Margalef et al. 1979). Modifications of this generalization have been proposed by Smayda (2002), who points out many exceptions to the relationship between water column stability and the success of dinoflagellates. Alternatively, Smayda proposes that the appearance of dinoflagellate blooms under stratified conditions is more coincidental than causal. He points out that the swimming ability of dinoflagellates is sufficient to deal with the typical mixing velocities encountered in most coastal ecosystems.

The results of the current study do not provide definitive corroboration for either view, although blooms of Pyrodinium bahamense var. bahamense are generally more frequent in the summer season in Florida, which is characterized by calmer winds than in the winter or spring. Similarly, the tidally restricted habitats where $P$. bahamense var. bahamense forms large blooms, such as the northern Indian River Lagoon and the northwest basin of Tampa Bay (i.e. Old Tampa Bay), would be considered relatively low-turbulence environments, compared to bays or coastal shelf habitats characterized by strong tidal mixing. However, blooms of similar magnitude occur in both narrow parts of the northern Indian River Lagoon, character- ized by limited wind fetch, and in the large open areas of the lagoon subject to strong wind mixing. At the same time, all of the habitats within the Indian River Lagoon and Tampa Bay where P. bahamense var. bahamense is abundant are shallow (typically $<3 \mathrm{~m}$ ) and normally polymictic, with little vertical stratification. It appears that $P$. bahamense var. bahamense blooms can occur over a considerable range of mixing conditions in terms of energy, albeit not necessarily in terms of mixing depth. Although most of the ecosystems included in this study were shallow, only a portion had significant populations of $P$. bahamense var. bahamen$s e$, indicating that depth may be a co-factor or possibly a prerequisite for the success of this species, but not without the influence of other contributing factors. The influence of depth on the distribution of $P$. bahamense var. bahamense may be more related to light availability than the physical aspects of turbulence. The scarcity of information on the light preference of $P$. bahamense var. bahamense precludes testing this hypothesis.

In terms of the nutrient availability axis, it is useful to go beyond the Mandala model and explore the C-S-R life-form strategy model, originally developed for freshwater phytoplankton (Reynolds 1995) and later applied to marine assemblages (Reynolds \& Smayda 1998, Smayda \& Reynolds 2001). Reynolds \& Smayda (1998) describe 3 basic life-form strategies for phytoplankton: (1) ' $\mathrm{C}$ ' species-small celled (biovolumes $<1000 \mu^{3}$ ), fast growing, and high nutrient preference; (2) 'S' species-large celled (biovolumes $>10000 \mathrm{\mu m}^{3}$ ), slow growing, high light preference, motile, and toxic or not eaten; and (3) ' $R$ ' speciesintermediate size, intermediate growth rate, low light tolerant, and adapted to well-mixed environments. Most of the characteristics of Pyrodinium bahamense var. bahamense fit into the ' $\mathrm{S}$ ' category, including large size, slow growth rates (Seliger et al. 1970), motility, toxin production (Landsberg et al. 2002), and apparent preference for shallow, light-rich environments. If the Reynolds' Intaglio model (Fig. 12) is applied to the question of spatial and temporal distribution, one would expect $P$. bahamense var. bahamense to be favored in environments with shallow mixing depths and during summer periods, when the immediate availability of inorganic nutrients is diminished or sporadic, even though the total potential nutrient pool (i.e. TP and TN), and therefore long-term biomass potential, may still be high.

As detailed in previous sections of the discussion, Pyrodinium bahamense var. bahamense often dominates the phytoplankton community in terms of relative biomass (i.e. percent of total phytoplankton biovolume) in the P-limited eastern basin of Florida Bay, despite the overall low standing crops of phytoplank- 


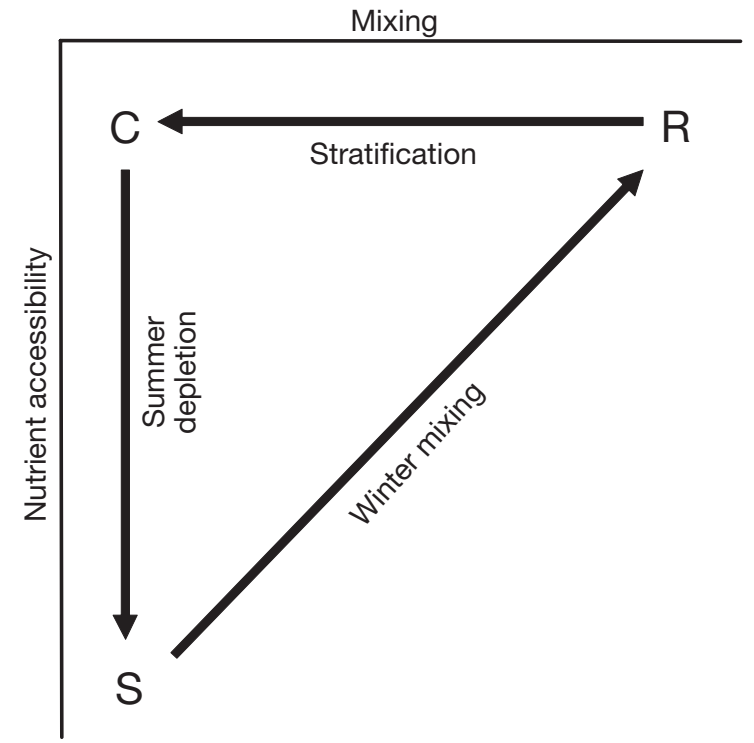

Fig. 12. Annual successional pattern of phytoplankton lifestrategy components C-S-R (see 'Discussion' for descriptions of individual components) in relation to nutrient accessibility and water column mixing (after Smayda \& Reynolds 2001)

ton in the region (Phlips et al. 1999). At the same time, it forms major blooms in the shallow, nutrient-rich regions of the Indian River Lagoon and Tampa Bay, but, in the summer and fall, when bioavailable inorganic nutrient levels are reduced. The observations of $P$. bahamense var. bahamense in both oligotrophic and eutrophic ecosystems may seem somewhat counter-intuitive, unless the issues of nutrient availability and utilization are viewed on multiple temporal scales. It is important to distinguish between the immediate rapid growth response to large nutrient pulses versus a more sustained strategy of nutrient accumulation and growth over time in an environment of smaller nutrient pulses. Spring rainfall events have the potential to produce significant inputs of bioavailable inorganic phosphorus and nitrogen, based on washout of nutrients accumulated in the watershed over the winter. The latter pulses may favor ' $C$ '-selected, fast-response-type species. It is interesting to note that outside of periods of $P$. bahamense var. bahamense blooms in the Indian River Lagoon and Tampa Bay, picoplanktonic cyanobacteria or small-celled diatoms are often abundant (Badylak et al. 2004, 20006, Phlips et al. 2004a). This relationship is illustrated by the observed patterns of $P$. bahamense var. bahamense and cyanobacterial picoplankton abundance in Tampa Bay, where blooms of cyanobacterial picoplankton and small-celled diatoms, such as Skeletonema costatum, preceded and followed summer blooms of $P$. bahamense var. bahamense. The latter observation fits into the overall successional scheme described in the Intaglio model, which predicts a rise in the prominence of ' $\mathrm{C}$ ' species, like picoplankton, under conditions of high bioavailable nutrient load and elevated wind mixing, followed by a rise in 'S' species, like P. bahamense, as the relative amount of immediately available inorganic nutrients is diminished and the water column becomes more stable. The synchrony between picoplanktonic cyanobacterial blooms and the P. bahamense var. bahamense blooms observed in Tampa Bay also suggest the possibility that $P$. bahamense var. bahamense may engage in phagotrophy on picoplankton, as has been demonstrated for some other dinoflagellate taxa (Stoecker et al. 1997), although there is currently no direct evidence to support this hypothesis.

From a physiological perspective, the large size of Pyrodinium bahamense var. bahamense may provide greater potential for nutrient storage. Slower growth rates, under conditions of smaller pulses of nutrients emanating from summer storm outflows from local watersheds and through internal recycling of nutrients, may allow the species to sustain high biomass levels. For example, the rainfall events in the relatively small watersheds that feed the northern Indian River Lagoon and the northwest region of Tampa Bay (i.e. Old Tampa Bay) generate comparatively small pulses of nutrients, setting up conditions for the accumulation of $P$. bahamense var. bahamense biomass. During the high rainfall period of 2001 through 2004 repeated pulses of phosphorus-rich water into the northern Indian River Lagoon were associated with frequent rainfall events, coinciding with the buildup of blooms (Phlips et al. 2004a, b). In an analogous way, the slow growth and hypothesized nutrient storage capability of $P$. bahamense var. bahamense help to explain its success in the strongly phosphorus-limited eastern Florida Bay, despite the lack of bloom potential.

In contrast to the success of Pyrodinium bahamense var. bahamense in the northern area of the Indian River Lagoon, it is generally absent in the central portion of the lagoon, during both drought and flood conditions. Two fundamental differences between the northern and central lagoon may help to explain this disparity: (1) the large, nutrient-rich watersheds that feed into the central lagoon result in a much larger water volume and nutrient loads than experienced in the northern lagoon, particularly in flood years and (2) because of the large watershed inputs and relative proximity of inlets (at Sebastian and Ft. Pierce) to the Atlantic Ocean, water residence times in the central lagoon are more strongly impacted by changes in rainfall than those in the northern Indian River Lagoon (Phlips et al. 2004b).

Overall, the spatial and temporal patterns of the distribution of Pyrodinium bahamense var. bahamense support the proposal of Smayda and Reynolds that 'life form properties, habitat preference and stochastic se- 
lective processes are more important in defining the character and magnitude of blooms than broad phylogenetic patterns' (Reynolds \& Smayda 1998, Smayda \& Reynolds 2001). In Florida, one of the most important stochastic processes that impact the potential for blooms is the temporal shift in rainfall, which directly effects several key factors that influence the success of $P$. bahamense var. bahamense, including water residence time, nutrient availability, and salinity variation. This is illustrated by the substantial rise in the frequency and intensity of $P$. bahamense var. bahamense blooms in the northern Indian River Lagoon during the high rainfall period from the summer of 2001 through 2004, compared to the drought years from 1998 through the spring of 2001. Rainfall patterns act as temporal modifiers of water residence time, nutrient availability, and salinity regime, while the basic physical, chemical, and biological characteristics of individual ecosystems, such as depth (in terms of light availability), basin morphology (in terms of flow restriction), watershed characteristics (in terms of nutrient richness and volume water displacement), and the structure of food webs (in terms of grazer response to toxins) define the specific environmental conditions experienced by P. bahamense var. bahamense.

Acknowledgements. The authors thank P. Hansen, T. Lynch, T. Grosskopf, M. Lockwood, J. Lockwood, C. Jett, J. Seerden, J. Frost, J. Fagans, and S. Youn for their assistance in the research effort. The research was, in part, supported by grants from the United States Department of Agriculture, the Suwannee River Water Management District, the St. Johns River Water Management District, and Sea Grant.

\section{LITERATURE CITED}

Anderson DM (1989) Cysts as factors in Pyrodinium bahamense ecology. In: Hallegraeff M, Maclean JL (eds) Biology, epidemiology and management of Pyrodinium red tides. ICLARM, Manila, p 81-88

Anton A, Alexander J, Estim A (2000) Harmful algal blooms in Malaysia: revisiting Kimanis Bay. In: Abstracts of the 9th international conference on harmful algal blooms. Sandy Bay, Tasmania

APHA (American Public Health Association) (1989) Standard methods for the analysis of water and wastewater, 17th edn. APHA, Washington, DC

Azanza RV, Taylor FJRM (2001) Are Pyrodinium blooms in the Southeast Asian region recurring and spreading? A view at the end of the millenium. Ambio 30:356-364

Badylak S, Phlips EJ (2004) Spatial and temporal patterns of phytoplankton abundance and composition in a subtropical lagoon, the Indian River Lagoon, Florida, USA. J Plankton Res 26:1-22

Badylak S, Kelly K, Phlips EJ (2004) A description of Pyrodinium bahamense from the Indian River Lagoon, Florida, USA. Phycologia 43:653-657

Badylak S, Philips EJ, Baker P, Fajans J (2006) Distributions of phytoplankton in Tampa Bay estuary, USA. Bull Mar Sci (in press)
Balech E (1985) A revision of Pyrodinium bahamense Plate (Dinoflagellata). Rev Palaeobot Palynol 45:17-34

Bledsoe E, Phlips EJ (2000) Nutrient versus light limitation of phytoplankton in the Suwannee River and Estuary. Estuaries 23:458-473

Bledsoe E, Phlips EJ, Jett C, Donnelly K (2004) Nutrient loading and hydrodynamic influences on phytoplankton standing crops in an inner-shelf estuary, the Suwannee River estuary, Florida, USA. Ophelia 58:29-47

Fahnenstiel GL, Carrick HJ (1992) Phototrophic picoplankton in Lakes Huron and Michigan: abundance, distribution, composition and contribution to biomass and production. Can J Fish Aquat Sci 49:379-388

Hallegraeff GM (1993) A review of harmful algal blooms and their apparent global rise. Phycologia 32:79-99

Knoppers B, Kjerfve B, Carmouze JP (1991) Trophic state and water turn-over time in six choked coastal lagoons in Brazil. Biogeochemistry 14:147-166

Landsberg JH (2002) The effects of harmful algal blooms on aquatic organisms. Rev Fish Sci 10:113-390

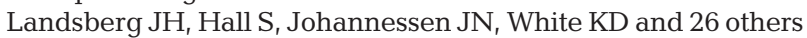
(2002) Pufferfish poisoning: widespread implications of saxitoxin in Florida. In: Abstracts of the 10th international harmful algal bloom conference. IOC-UNESCO, Paris

Livingston RJ (2001) Eutrophication processes in coastal systems. CRC Press, Boca Raton, FL

Maclean JL (1989) Indo-Pacific red tides, 1985-1988. Mar Pollut Bull 20:304-310

Margalef R (1961) Hidrografia y fitoplancton de un area marina de la costa meridional de Puerto Rico. Investig Pesq 18: 33-96

Margalef R (1978) Life forms of phytoplankton as survival alternatives in an unstable environment. Oceanol Acta 1: 493-509

Margalef R, Estrada M, Blasco D (1979) Functional morphology of organisms involved in red tides, as adapted to decaying turbulence. In: Taylor $\mathrm{D}$, Seliger H (eds) Toxic dinoflagellate blooms. Elsevier, New York, p 89-94

Monbet Y (1992) Control of phytoplankton biomass in estuaries: a comparative analysis of microtidal and macrotidal estuaries. Estuaries 15:563-571

Murrell MC, Lores EM (2004) Phytoplankton and zooplankton dynamics in a subtropical estuary: importance of cyanobacteria. J Plankton Res 26:371-382

Paerl HW (1988) Nuisance phytoplankton blooms in coastal, estuarine and inland waters. Limnol Oceanogr 33:823-847

Parsons TR, Maita Y, Lalli CM (1984) A manual of chemical and biological methods for seawater analysis. Pergamon Press, New York

Phlips EJ, Badylak S (1996) Spatial variability in phytoplankton standing crop and composition in a shallow inner shelf lagoon, Florida Bay, Florida. Bull Mar Sci 58:203-206

Phlips EJ, Zeman C, Hansen P (1989) Growth, photosynthesis, nitrogen fixation and carbohydrate production by a unicellular cyanobacterium, Synechococcus sp. (Cyanophyta). J Appl Phycol 1:137-145

Phlips EJ, Badylak S, Lynch TL (1999) Blooms of the picoplanktonic cyanobacterium Synechococcus in Florida Bay. Limnol Oceanogr 44:1166-1175

Phlips EJ, Badylak S, Grosskopf T (2002) Factors affecting the abundance of phytoplankton in a restricted subtropical lagoon, the Indian River Lagoon, Florida, USA. Estuar Coast Shelf Sci 55:385-402

Phlips EJ, Badylak S, Youn S, Kelley K (2004a) The occurrence of potentially toxic dinoflagellates and diatoms in a subtropical lagoon, the Indian River Lagoon, Florida, USA. Harmful Algae 3:39-49 
Phlips EJ, Love N, Badylak S, Hansen P, John CV, Gleeson R (2004b) A comparison of water quality and hydrodynamic characteristics of the Guana Tolomato Matanzas National Estuarine Research Reserve and the Indian River Lagoon in Florida. J Coast Res (Spec Issue) 45:93-109

Plate L (1906) Pyrodinium bahamense n. g., n. sp. die LeuchtPeridinee des 'Feuersees' von Nassau, Bahamas. Arch Protistenkd 7:411-429

Reynolds CS (1988) Functional morphology and the adaptive strategies of freshwater phytoplankton. In: Sandgren CD (ed) Growth and reproductive strategies of freshwater phytoplankton. Cambridge University Press, Cambridge, p 388-433

Reynolds CS (1995) Successional change in the planktonic vegetation: species, structures, scales. In: Joint I (ed) The molecular ecology of aquatic microbes. Springer-Verlag, Berlin, p 115-132

Reynolds CS, Smayda TJ (1998) Principles of species selection and community assembly in the phytoplankton: further explorations of the Mandala. In: Proceedings of the 7th international conference on harmful algae. IOC-UNESCO, Paris

Richardson K, Jørgensen BB (1996) Eutrophication, definition, history and effects. In: Jørgensen BB, Richardson K (eds) Eutrophication in coastal marine ecosystems. American Geophysical Union, Washington, DC, p 1-20

Rijstenbil JW (1988) Selection of phytoplankton species in culture by gradual salinity changes. Neth J Sea Res 22: 291-300

Sartory DP, Grobbelaar JU (1984) Extraction of chlorophyll a from freshwater phytoplankton for spectrophotometric analysis. Hydrobiologia 114:177-187

Schmidt N, Luther ME (2002) ENSO impacts on salinity in Tampa Bay, Florida. Estuaries 25:976-984

Seliger HH, Carpenter JH, Loftus M, McElroy WD (1970) Mechanisms for the accumulation of high concentrations of dinoflagellates in a bioluminescent bay. Limnol Oceanogr 15:234-245

Sheng YP, Peene S, Lui YM (1990) Numerical modeling of tidal hydrodynamics and salinity transport in the Indian River Lagoon. Fla Sci 50:49-61

Shumway SE (1990) A review of the effects of algal blooms on shellfish and aquaculture. J World Aquac Soc 21:65-104

Smayda TJ (1978) From phytoplankters to biomass. In: Sournia A (ed) Phytoplankton manual. UNESCO, Paris, p 273279

Smayda TJ (1980) Phytoplankton species succession. In: Morris I (ed) The physiological ecology of phytoplankton. Blackwell, Oxford, p 493-570

Smayda TJ (1989) Primary production and the global epidemic of phytoplankton blooms in the sea: A linkage? In: Cosper EM, Bricelj VM, Carpenter EJ (eds) Novel phytoplankton blooms. Springer-Verlag, New York, p 449-484

Smayda TJ (1997) Harmful algal blooms: their ecophysiology and general relevance to phytoplankton blooms in the sea. Limnol Oceanogr 42:1137-1153

Editorial responsibility: Otto Kinne (Editor-in-Chief), Oldendorf/Luhe, Germany
Smayda TJ (2002) Turbulence, watermass stratification and harmful algal blooms: an alternative view and frontal zone as 'pelagic seed banks'. Harmful Algae 1:95-112

Smayda TJ, Reynolds CS (2001) Community assembly in marine phytoplankton: application of recent models to harmful dinoflagellate blooms. J Plankton Res 23: $447-461$

Smith NP (1993) Tidal and non-tidal flushing of Florida's Indian River Lagoon. Estuaries 16:739-746

Sombrito EZ, Bulos AdM, Sta Maria EJ, Honrado MCV, Azanza RV, Furio EF (2004) Application of ${ }^{210} \mathrm{~Pb}$-derived sedimentation rates and dinoflagellate cyst analyses in understanding Pyrodinium bahamense harmful algal blooms in Manila Bay and Malampaya Sound, Philippines. J Environ Radioact 76:177-194

Sournia A (1982) Form and function in marine phytoplankton. Biol Rev 57:347-394

Steidinger KA (1979) Collection, enumeration and identification of free-living marine dinoflagellates. In: Taylor DL, Seliger HH (eds) Toxic dinoflagellate blooms. Elsevier, New York, p 435-442

Steidinger KA, Tester LS, Taylor FJR (1980) A redescription of Pyrodinium bahamense var. compressa (Böhn) stat. nov. from Pacific red tides. Phycologia 19:329-337

Stoecker DK, Li A, Coats DW, Gustafson DE, Nannen MK (1997) Mixotrophy in the dinoflagellates Prorocentrum minimum. Mar Ecol Prog Ser 152:1-12

ter Braak CJF (1987) The analysis of vegetation-environment relationships by canonical correspondence analysis. Vegetation 69:69-77

Turner JT, Tester PA (1997) Toxic marine phytoplankton, zooplankton grazers, and pelagic food webs. Limnol Oceanogr 42:1203-1214

Turner JT, Tester PA, Hansen PJ (1998) Interactions between toxic marine phytoplankton and metazoan and protistan grazers. In: Anderson DM, Cembella AD, Hallegraeff GM (eds) The physiological ecology of harmful algal blooms. NATO ASI Series, Springer-verlag, Berlin, p 453-474

Usup G, Azanza RV (1998) Physiology and dynamics of the tropical dinoflagellate Pyrodinium bahamense. In: Anderson DM, Cembella AD, Hallegraeff GM (eds) The physiological ecology of harmful algal blooms. NATO ASI Series, Springer-Verlag, Berlin, p 81-94

Utermöhl H (1958) Zur Vervollkommnung der quantitativen Phytoplankton-Methodik. Mitt Int Ver Theor Angew Limnol 9:1-38

Villanoy CL, Corrales RA, Jacinto GS, Cuaresma Jr NT, Crisostomo RC (1996) Towards the development of cystbased model for Pyrodinium red tides in Manila Bay, Philippines. In: Yasumoto T, Oshima Y, Fukuyo Y (eds) Harmful and toxic algal blooms. IOC-UNESCO, Paris, p 189-192

Wall D, Dale B (1969) The 'hystrichosphaerid' resting spore of the dinoflagellate Pyrodinium bahamense Plate, 1906. J Phycol 5:140-149

Submitted: October 25, 2005; Accepted: March 9, 2006 Proofs received from author(s): September 11, 2006 